\title{
Avaliação de desempenho da revista Terræ Didatica na área de Geociências
}

\author{
An asSessment of the performance of TerRe Didatica, a Geosciences JOURNaL
}

\author{
Flávio Lopes Linquevis ${ }^{1}$, Celso Dal Ré Carneiro², Pedro Wagner Gonçalves ${ }^{3}$ \\ 1- Mestre pelo Programa de Pós-Graduação em Ensino e História de Clências da Terra, Instituto de Geociências, Universidade Estadual de Campinas, Campinas, SP. \\ E-MAIL: FLAVIO.LINQUEVIS@UOL.COM.BR \\ 2- Programa de Pós-Graduação em Ensino e História de Ciências da Terra, Instituto de Geociências, Universidade Estadual de Campinas, Bolsista do CNPQ, Brasil. \\ CAMPINAS, SP. E-MALL: CEDREC@IGE.UNICAMP.BR \\ 3- Programa de Pós-Graduação em Ensino e História de Ciências da Terra, Instituto de Geociências, Universidade Estadual de Campinas. Campinas, SP. \\ E-MAIL:PEDROG@IGE.UNICAMP.BR
}

Abstract: This article describes results of a research about the editorial performance of Terræ Didatica (TD). It puts in evidence that the educational journal of the University of Campinas has been well accepted by the community. The research sought to evaluate whether the journal effectively acts as a dissemination tool of geoscientific knowledge. The instruments are Likert questionnaires and interviews with readers, authors, editors and editorial board members, aimed at measuring a series of aspects of interest for Geosciences teaching. The answers strongly support the effort of TD for disseminating high quality articles, both technical and didactic, as has been rightly done so far. The data shows the existence of a critical mass of researchers, teachers, students and other interested parties capable of actively promoting the dissemination of Geosciences in Brazilian society and even forming a recognizable community at the international level. It was suggested the journal to go beyond the context of public institutions of higher education.

\section{Manuscrito:}

Recebido: 26/09/2017

Corrigido: 06/12/2017

Aceito: 14/01/2018

Citation:. Linquevis F L. , Carneiro C.D.R., Pedro Wagner Gonçalves P.W. 2018. Avaliação de desempenho da revista Terræ Didatica na área de Geociências Terræ Didatica, 14(2):87-108. URL: http://www.ige.unicamp.br/terraedidatica/.

Keywords:Geology, Earth Sciences, Education, Geography, publishing, popularization of Science, environment.

\section{Introdução}

Pesquisa de mestrado do primeiro autor (Linquevis 2017), sob orientação do segundo, junto ao Programa de Pós-Graduação em Ensino e História de Ciências da Terra da Universidade Estadual de Campinas (Unicamp), estudou as características editoriais de Terre Didatica (TD), a revista educacional do Instituto de Geociências. A pesquisa procurou reunir elementos capazes de fortalecer TD no cenário de periódicos nacionais que disseminam conhecimento científico em Geociências, investigarando a imagem que vem sendo construída pela revista, a receptividade no meio acadêmico-educacional e a utilização, no ambiente escolar ou fora dele, de artigos publicados por TD.

O objetivo central do projeto foi investigar Terre Didatica. Em outro artigo (Carneiro \& Linquevis 2018) descrevemos e analisamos o sistema Likert desenvolvido na pesquisa e as correspondentes ferramentas, baseadas em questionários e entrevistas junto a leitores, autores, editores e membros do Conselho Editorial. Os resultados da pesquisa são detidamente apresentados e discutidos neste trabalho, que abrange a análise crítica do padrão editorial e da imagem construída pela revista ao longo do tempo. A pesquisa antecede, contudo, a decisão dos editores das revistas Terra e Terre Didatica no sentido de reunir os dois títulos em um só a partir de 2018. O novo perfil trará crescimento editorial, com ampliação da periodicidade e do escopo.

A questão central foi: "Terre Didatica fortalece o ensino de Geociências e cumpre adequadamente seu papel?"

Terre Didatica, criada em 2005, publica resultados de pesquisas e estimula o intercâmbio de materiais didáticos e recursos educativos, veiculando artigos e matérias que buscam difundir e debater resultados de pesquisas nas áreas de Ciências da Terra, Geografia e Ciências do Ambiente. Os objetivos são amplos: (a) apoiar os cursos brasileiros de graduação e pós-graduação, notadamente nas áreas de Geologia, Geografia e formação de professores; (b) promover a difusão das Ciências da Terra na educação básica. O periódico mantém 
duas versões: impressa e eletrônica de acesso livre e, como consequência, mantém dois registros de International Standard Serial Number (ISSN): versão impressa 1679-2300 e versão online 1980-4407.

A periodicidade é quadrimestral desde 2014. A versão impressa é gratuitamente distribuída, com tiragem atual de 1.000 exemplares. O Corpo Editorial é composto por editor-chefe, editor-associado e conselho consultivo formado por profissionais de alta qualificação, assim distribuídos: 06 membros do exterior, 08 membros diretamente vinculados à Unicamp e 25 membros nacionais externos, de várias regiões do País, totalizando 39 membros. A revista incentiva a publicação de artigos bilíngues e edição de cadernos temáticos. O conteúdo se divide em dois grupos (Linquevis 2017): um é dirigido a professores e profissionais da área de ensino geocientífico e outro destina-se a profissionais formados, alunos de graduação ou técnicos na área de Geociências. Os artigos do segundo grupo são redigidos de forma mais técnica e menos didática, utilizando linguajar e formatação pesada do ponto de vista de um aluno do ensino fundamental ou médio comum, podendo colocar em risco a possibilidade de a revista atingir seu objetivo no subgrupo de docentes e estudantes de educação básica.

\section{Objetivos e motivação}

Este artigo objetiva apresentar os resultados de pesquisa que avaliou a relação construída pelos leitores, autores e revisores junto à revista Terrex Didatica. Pretendeu-se mensurar se a revista desempenha bem, e em qual medida, o papel originalmente proposto, de ferramenta de difusão do conhecimento geocientífico. A pesquisa buscou ainda investigar a utilização, no ambiente escolar ou fora dele, de artigos publicados, tendo sido necessário identificar: (a) o público-alvo a que se destinam os artigos; (b) materiais didáticos e métodos difundidos pela revista; (c) quais ações e práticas são desenvolvidas por docentes, alunos e outros interessados com base nos materiais publicados; (d) qual a avaliação do impacto da existência da revista na comunidade e no público que normalmente visita suas páginas, sobretudo a edição eletrônica, cuja frequência de acessos (diária, semanal, mensal, anual) é mais facilmente mensurada.

A elaboração da dissertação (Linquevis 2017) exigiu um distanciamento entre pesquisador e orientador, uma vez que o Orientador exerce funções de editor-chefe do periódico analisado. Houve total liberdade tanto para a coleta de dados, quanto para análise destes. A pesquisa baseou-se em três premissas (Carneiro \& Linquevis 2018):

1. A concepção de que a Educação em Ciências da Terra é instrumento essencial para formar cidadania consciente, estimular o consumo sustentável e promover o desenvolvimento de políticas e programas que visem à gestão ambiental dos sistemas produtivos.

2. Todo processo editorial obedece a mecanismos de avaliação que requerem o confronto de diversos argumentos e até mesmo opiniões antagônicas sobre cada manuscrito avaliado. Aceitar ou rejeitar um manuscrito, em resumo, resulta de um diálogo que se estabelece entre integrantes do processo: autor/es-editor/ es-avaliador/es. Quando bem conduzidas, a polêmica e a controvérsia trazem como resultado prático um aprimoramento considerável da comunicação e da qualidade do trabalho final publicado.

3. A busca pela excelência acadêmica está no âmago do processo editorial, uma vez que os resultados e conclusões de cada trabalho publicado são exaustivamente avaliados e até mesmo, em certos casos, validados, para merecer a confiança das comunidades científica e educacional, assim como de geólogos e outros profissionais no caso das Geociências.

Uma revista pode e, dizemos mais, deve, na condição de mídia de comunicação de massa, cumprir o papel de ferramenta de auxílio na disseminação de conhecimento a um amplo espectro de pessoas, funcionando como um canal de comunicação eficiente.

Uma revista é um tipo de mídia de comunicação de massa que deve disseminar conhecimento a um amplo espectro de pessoas, funcionando como um canal de comunicação eficiente. Além disso, o trabalho se propõe a responder às seguintes perguntas acessórias:

- Os artigos, comunicações e material didático publicados por Terre Didatica atendem às expectativas de seus leitores e consulentes?

- O perfil editorial construído ao longo dos anos atende à demanda do público-alvo e ajuda a difundir o conhecimento geocientífico?

- Como se pode melhorar significativamente a qualidade dos materiais e textos divulgados em Terre Didatica? 
Os instrumentos desenvolvidos na pesquisa são apresentados e discutidos por Carneiro \& Linquevis (2018), que examinam as dificuldades de se avaliar o desempenho de revistas científicas, com destaque para o Fator de Impacto de Periódicos (FIP), criado nos anos 1950 por Eugene Garfield (Garfield 2006). O FIP mede a quantidade de citações que são feitas para um determinado artigo publicado em um periódico, em outras obras científicas do mesmo periódico durante os dois anos subsequentes à publicação. Diante de críticas e distorções que vêm sendo levantadas em relação ao FIP, e devido ao perigo de existir manipulação, Carneiro \& Linquevis (2018) concluem que o "Fator de Impacto de Periódicos não causa impacto", mas isso não significa que se deva abandonar a avaliação qualitativa para se aferir a qualidade e importância de um dado trabalho (Verma 2015).

\section{Pesquisa investigativa junto a autores, revisores e leitores}

Os questionários foram produzidos em arquivo no formato Word ${ }^{\circledR}$ e distribuídos por e-mail. A consulta foi encaminhada pelo e-mail da própria revista, mais de uma vez, por meio do endereço <terraedidatica@ige.unicamp.br>.Após duas tentativas com baixo número de respostas, foi encaminhada mensagem pelo e-mail <flaviolinquevis@ ige.unicamp.br>.

\section{Resultados obtidos sobre avaliação dos autores, revisores e leitores}

Obtivemos poucas adesões à pesquisa, ficando entre $12 \%$ a $22 \%$ de efetivas respostas do universo total. Isso quando falamos dos editores e autores. $\mathrm{O}$ percentual cai ainda mais quando se trata de leitores. A pesquisa obteve 34 respostas de Autores, 28 respostas de Revisores e 60 respostas de Leitores. No caso desta última categoria o número não pode ser considerado representativo, mas os dados são significativos para Autores e, principalmente, para os membros do conselho editorial e avaliadores externos. É possível extrair informações importantes do conjunto, como veremos a seguir.

\section{Autores}

Foram enviados por e-mail duzentos e oitenta e três (283) questionários para autores de artigos assim relacionados no mailing-list da revista, incluin- do aqueles que não tiveram artigos aprovados ou que ainda aguardam aprovação. Recebemos 34 respostas desse universo, ou seja, 12,01\% dos pesquisados retornaram a consulta preenchida. A pesquisa contava com 31 perguntas, entre abertas, fechadas e de escala Likert. O escopo foi identificar o perfil do/a autor/a, suas visões e expectativas em relação ao periódico, identificar se cada autor/a teve suas expectativas confirmadas, atingidas e/ou superadas. Foi aberta ainda a possibilidade de os autores apresentarem sugestões, opiniões, críticas ou elogios ao final. Como uma constante em todos os grupos pesquisados, para plena garantia da idoneidade nas respostas, perguntamos inicialmente se cada um gostaria de ter sua identidade revelada; obtivemos as respostas sumariadas na Figura 1a.

$71 \%$ dos pesquisados concordaram em ter sua identidade revelada, enquanto $29 \%$ não. O interessante é perceber uma tendência na pergunta; a grande maioria dos pesquisados que afirmaram não querer ter sua identidade revelada era do sexo feminino. Seguem perguntas de identificação dos autores, como nome e outras questões de localização espacial e social, tais como local onde mora. As respostas encontram-se reunidas na Figura 1b. A maciça maioria localiza-se na região sudeste, totalizando $54 \%$ dos pesquisados, distribuídos em ordem decrescente entre São Paulo, Rio de Janeiro e Minas Gerais. Vimos também a adesão de autores da Argentina e Portugal. O que nos demonstra que é necessária a ampliação de captura de autores nas regiões Centro-Oeste, Norte e Nordeste, devido à baixa adesão de estados nestas regiões. Algo que pode ser alcançado caso seja ampliada a divulgação da revista. Ao contrário dos outros grupos pesquisados, em relação ao sexo, o grupo de autores é homogêneo, ficando dividido em partes exatamente iguais, como indica a Figura 1c. Em relação à idade chegamos ao resultado sumariado na Figura 1d.

Duas faixas etárias se destacaram entre os pesquisados, encontramos $29 \%$ dos entrevistados na faixa de 51 a 60 anos e logo após, 26\% de pesquisados com idades de 31 a 40 anos. Ficando as faixas de 41 a 50 anos e 61 a 70 anos com 12\% cada. Este gráfico se complementa com os dois seguintes: a concentração a faixa etária reflete bem este grupo. Na maior faixa, encontramos autores que são docentes de instituições de ensino superior; a segunda faixa compreende autores os quais estão ainda se especializando em cursos de pós graduação. Vejamos, portanto, em complemento ao anterior, respostas sobre a escolaridade, cujas respostas encontram-se na Figura 1e. A maciça maioria, 44\%, 
Concorda ter sua identidade revelada?

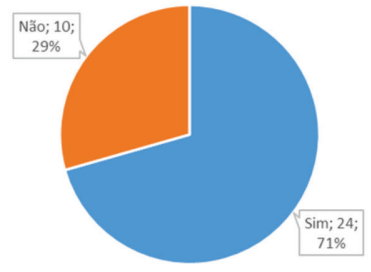

Local de residência

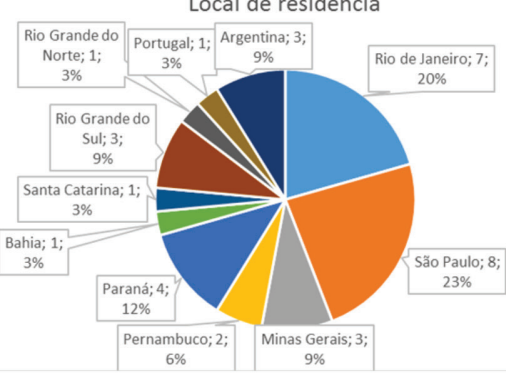

Sexo

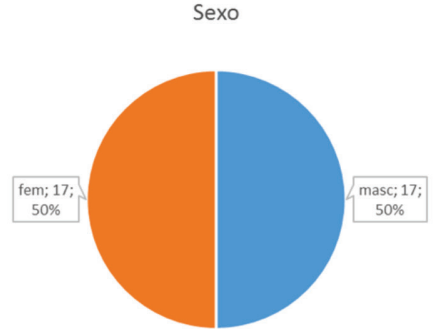

C

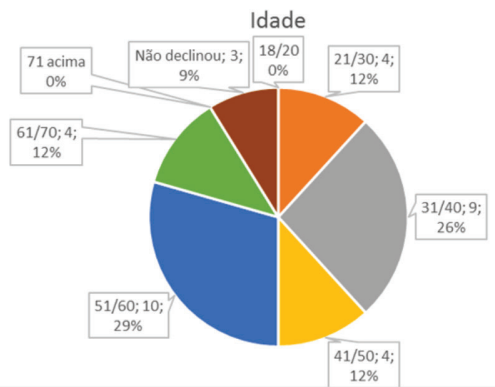

Escolaridade

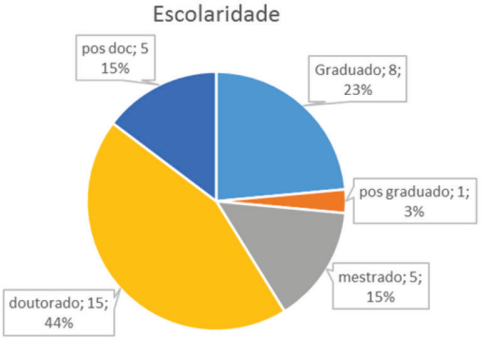

A

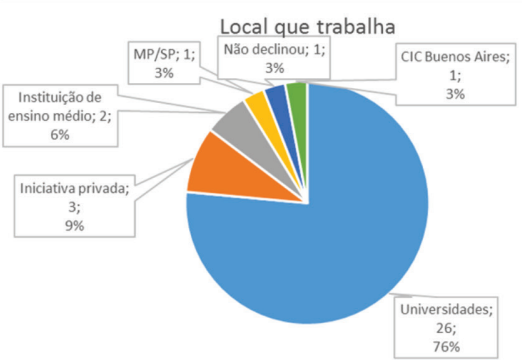

F

Possui Currículo Lattes

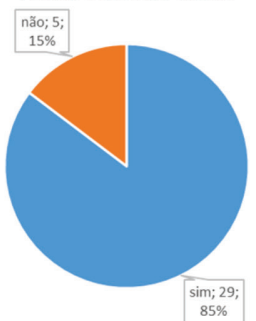

G

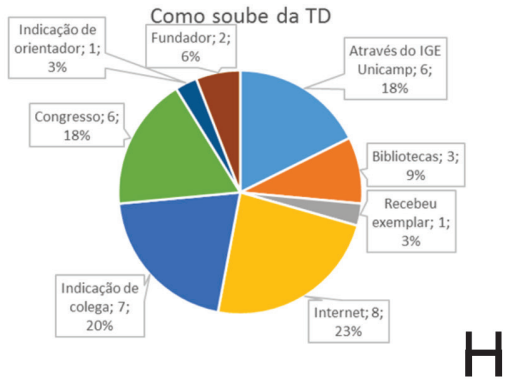

Opinião sobre o processo de avaliação do artigo

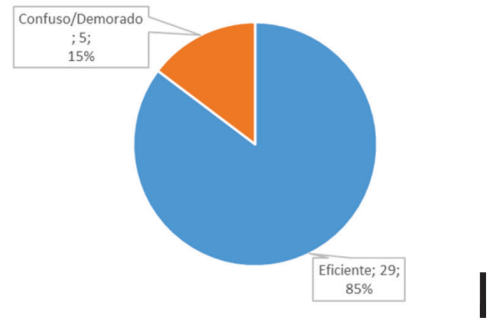

Motivo que levou a publicar na Revista

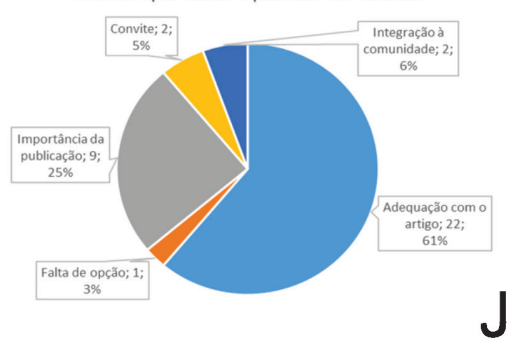

Figura 1. Respostas dos Autores ao questionário, parte A: (a) percentual de autores que concordam em ter suas identidades reveladas; (b) percentuais em relação aos locais de moradia; (c) percentuais em relação ao sexo; (d) percentuais em relação a idade; (e) percentuais em relação à escolaridade; (f) percentuais em relação ao local de trabalho; (g) percentual de autores que possuem currículo na plataforma Lattes; (h) percentuais sobre a forma de como os autores ficaram sabendo da revista; (i) percentuais sobre a opinião dos autores sobre o processo de avaliação de seus artigos; (j) percentuais sobre motivos que levaram os autores a publicar na revista 
se encontra naqueles que possuem doutorado, seguida por graduados com $23 \%$. Pós-doutores e mestres concentram $15 \%$ cada do total das respostas. Em relação ao local em que o entrevistado trabalha, podemos utilizar um filtro em relação ao tipo de origem do capital investido na instituição, separando em duas espécies, privado e público; as respostas acham-se sumariadas na Figura 1f. Em relação à iniciativa pública, encontramos $85 \%$ dos entrevistados, abrangendo $76 \%$ das Universidades, todas públicas, não encontramos a adesão de integrantes das Universidades privadas. Em soma aos $76 \%$ citados, temos também 6\% em instituições de ensino médio, também público, $3 \%$ de integrantes do Ministério Público de São Paulo e finalmente 3\% de integrantes da Comisión de Investigaciones Científicas de Buenos Aires, uma instituição mantida pelo governo argentino.

Por haver grande número de integrantes de universidades, vemos a maioria dos entrevistados indexados na plataforma Lattes do CNPq (Fig. 1g). A internet foi o canal mais eficaz na divulgação da publicação, $23 \%$, seguido por $20 \%$ de divulgação boca a boca (Fig. 1h). Aqueles que conheceram a revista por meio de relacionamento com o Instituto de Geociências da Unicamp e congressos ficaram com $18 \%$ cada. Isso indica que realmente o Acesso Aberto é um grande facilitador em questão à visualização da revista, o que deve ser mais incentivado. Quanto ao processo de produção dos artigos, inicialmente em relação ao processo de avaliação a que foram submetidos os manuscritos, $85 \%$ dos autores consideraram o processo eficiente (Fig. 1i). O restante, 15\%, consideraram demorado e confuso. Mesmo tendo como resposta que o processo de avaliação é eficiente, para nos adequar à plataforma SciELO, como vimos, devemos criar um modo de acompanhamento online, para que os autores visualizem o status das avaliações a qualquer tempo. Em relação ao motivo que levou os autores a escolherem Terre Didatica como sendo a publicação ideal para seus artigos, detectamos que a grande maioria, $61 \%$, escolheu a publicação devido à adequação com o artigo que produziram (Fig. 1j). $\mathrm{Na}$ sequência, 25\% dos autores escolheram pela importância da revista. Interessante salientar que um dos entrevistados indicou ter escolhido TD por falta de opção, ou seja, por não haver outra publicação no segmento.

É desejável que se alcance patamar percentual maior na resposta "Importância da revista". Um dos caminhos seria aumentar o FIP, talvez pela indexação de documentos publicados produzidos por autores reconhecidos em Geociências. Em relação à quantidade de artigos submetidos e aceitos obtivemos os seguintes resultados dentre os autores pesquisados (Fig. 2a): 24 autores submeteram apenas 1 artigo, sendo que dos 24, 19 tiveram os artigos publicados. Um conjunto de 6 autores submeteu 2 artigos, mas somente 5 tiveram os dois artigos publicados; 4 autores submeteram mais de dois artigos, sendo que três desses autores tiveram todos os seus artigos publicados.

Espera-se que os autores divulguem seus trabalhos. Em relação a este quesito recebemos as respostas sumariadas na Figura 2b. Infelizmente $41 \%$ não responderam, mas dos que responderam 29\% divulgaram seus trabalhos para colegas e alunos, seguidos de $15 \%$ dos entrevistados que divulgaram apenas a colegas, 9\% divulgaram para alunos somente e 6\% não divulgou. Em relação à divulgação, queremos que os autores o façam, assim como os demais impactados pela revista e participantes do processo de publicação. Acreditamos que com a solução dada para o aumento do percentual de autores que buscam a publicação para seus artigos devido à importância da revista, também irá refletir sobre a questão (Fig. 2b). Daqueles autores que responderam, perguntamos então qual meio utilizam para divulgar seus trabalhos (Fig. 2c). 35\% dos entrevistados divulgaram seus trabalhos por e-mail ou elegeram a internet como meio de divulgação; imaginamos que quando os autores indicaram simplesmente a internet como sendo o meio utilizado, a resposta abrange blogs, portais especializados, portais de educação, tais como Moodle, TelEduc entre outros. 15\% indicou que realizou a divulgação em sala de aula. Isso nos mostra que o formato digital da revista é vital para a divulgação. Ao perguntarmos se os autores continuavam a acompanhar a revista, tivemos quase unanimidade na resposta sim: $97 \%$, sendo que apenas $3 \%$ declinaram que não.

Aos autores que continuam acompanhando, perguntamos qual o meio que utilizam para se manter atualizados quanto ao conteúdo (Fig 2d). Verificamos que $61 \%$ dos autores que responderam à pesquisa continuam acompanhando a revista pelo meio digital (Fig. 2d), 15\% declinaram que acompanham tanto pelo meio digital quanto por meio da revista impressa, e $12 \%$ indicaram apenas a revista impressa. O mesmo percentual, ou seja, $12 \%$, não declinou o meio que utiliza para acompanhar a publicação. Podemos tirar das duas 


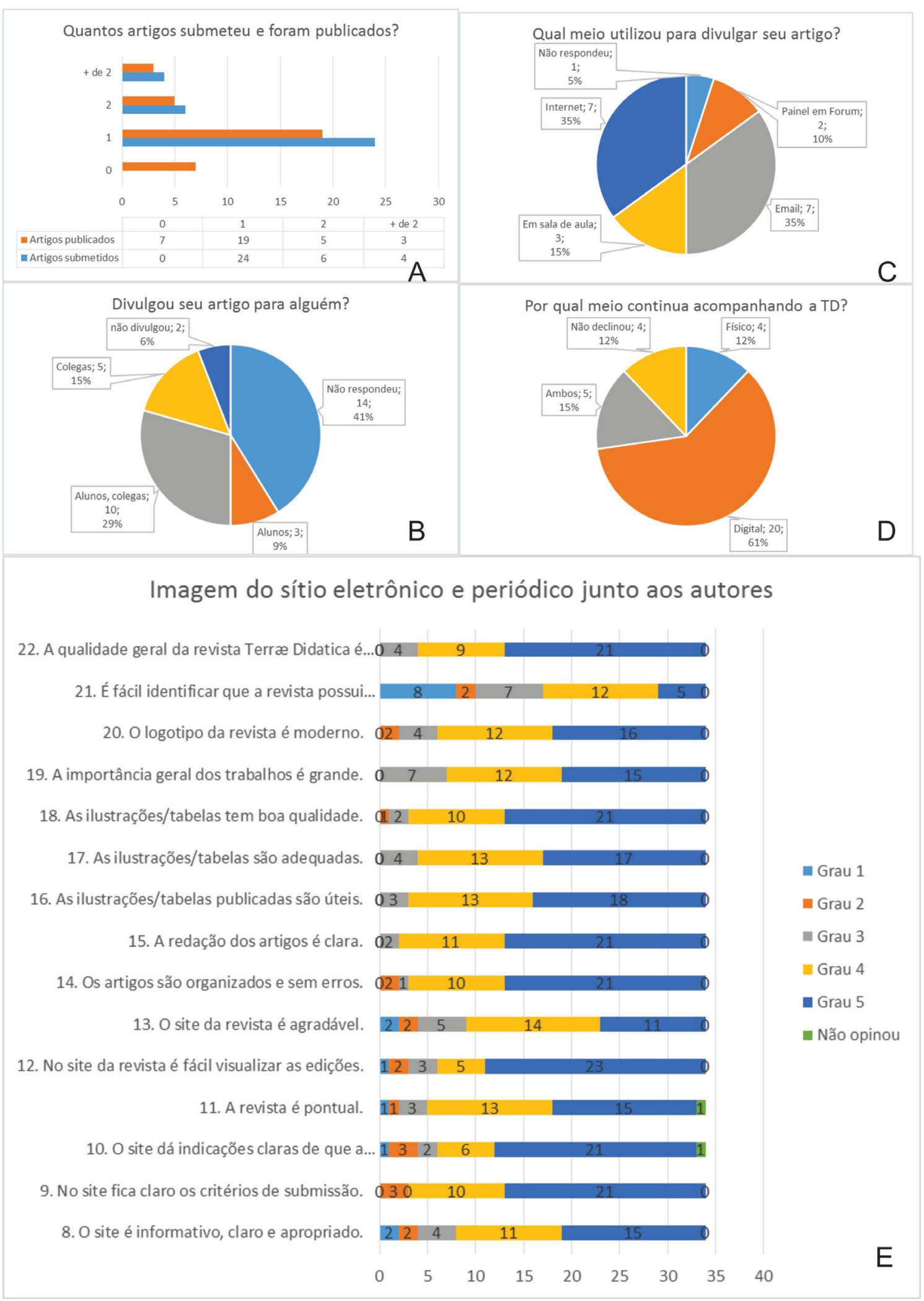

Figura 2. Respostas dos Autores ao questionário, parte B: (a) volume de artigos submetidos e publicados pelos autores; (b) quais tipos de pessoas a quem os autores divulgaram seus artigos; (c) quais meios de comunicação foram escolhidos pelos autores para divulgar seus artigos; (d) quais meios de mídia os autores utilizam para acompanhar a revista; (e) sequência de perguntas sobre a imagem do sítio eletrônico e do periódico junto aos autores 
questões que a ampliação do Acesso Livre por meio da internet, quer pelo próprio sítio eletrônico, quer pela indexação em outras plataformas, deve continuar e ser incentivado.

Fizemos então 15 perguntas sequenciais (Fig. 2e) construídas conforme a escala Likert (Linquevis 2017), com o intuito de verificar alguns elementos em relação à imagem da revista e seu sítio eletrônico. As respostas deveriam ser dadas em gradação, de 1 a 5 , sendo que grau 1 é aquele do qual o pesquisado discorda totalmente, já no grau 2 o pesquisado concorda pouco, grau 3 é aquele que o pesquisado acredita nem discordar ou concordar totalmente, grau 4 se aproxima da concordância plena e finalmente no grau 5 o pesquisado concorda plenamente com a assertiva realizada. Importante observar que as questões foram elaboradas em forma positiva, tais como: expõe bem o conteúdo, o sítio eletrônico é claro, a revista é pontual etc. Então, atribuindo grau 1 os autores declaram que não concordam com a assertiva, grau 2 discordam parcialmente, grau 3 concordam em parte, grau 4 concordam parcialmente e atribuindo grau 5 concordam plenamente.

A primeira pergunta feita foi se o sítio eletrônico da revista é informativo, claro e apropriado. Tivemos a grande maioria atribuindo entre os graus 4 e 5 , sendo que o grau 5 obteve mais respostas. A segunda pergunta foi se o sítio eletrônico da revista expõe de forma clara os critérios de submissão dos artigos. Novamente vemos a maioria atribuindo o grau 5 como o ideal para tal resposta. A próxima pergunta feita foi de que se fica claro que a revista possui a forma de submissão apenas por meio eletrônico. Obtivemos resultado exatamente igual ao da pergunta anterior, sendo que nesta pergunta as demais gradações receberam um número pequeno, mas de forma mais pulverizada. Queríamos saber se os autores viam a publicação como sendo pontual, ou seja, se respeita a periodicidade estabelecida. Os graus 4 e 5 receberam a maioria das respostas (Fig. 2e). Sendo assim, acreditamos que a maioria dos autores entende que a revista assegura pontualidade. De todas as perguntas, a próxima foi a que mais recebeu respostas no grau 5 máximo: perguntamos se é fácil visualizar no sítio eletrônico as edições atuais e anteriores da revista. O periódico recebeu o grau 5 , com grande similaridade nas respostas. Perguntamos ainda se o sítio eletrônico é agradável e visualmente adequado. Repete-se a tendência de respostas concentradas nos graus $4 \mathrm{e}$ 5 , mas desta vez a maioria das respostas ficou com o grau 4. Queríamos saber o que os autores acham sobre a organização e isenção de erros e incorreções nos artigos. Mais uma vez a maioria acredita que sim, diante da concentração de respostas no grau 5. Em relação a gramática e sintaxe, os autores atribuíram em sua maioria grau 5 , considerando então tais elementos citados como claros e sem erros. As ilustrações e tabelas foram consideradas úteis e indispensáveis, pois receberam em sua maioria gradação 4 e 5 . Na sequência, queríamos saber se as mesmas tabelas e ilustrações possuem adequado nível de conteúdo e informação. Os graus eleitos pelos autores foram 4 e 5 . Ainda em relação às tabelas e ilustrações, perguntamos se estas são de boa qualidade e legibilidade, sendo que novamente os graus que receberam mais respostas foram 4 e 5 (Fig. 2e). Passamos então para a gradação de importância em relação aos trabalhos publicados. Obtivemos uma concentração pulverizada entre os graus 4 e 5 , mas o grau 3 também recebeu quantidade considerável de respostas, o que nos leva a crer ser preciso indexar a revista em outras plataformas.

Em relação à adequação gráfica da revista, perguntamos se o logotipo da revista é moderno, de boa qualidade visual e legível. As respostas se concentraram nos graus 4 e 5 , mas tendo poucas respostas pulverizadas nos outros graus, sendo que não houve nenhuma resposta no grau 1. Aspecto importante para manutenção da publicação refere-se a patrocinadores, pois a revista é subsidiada por valores advindos de empresas privadas, as quais recebem um espaço nas publicações e no sítio eletrônico para divulgarem suas marcas e produtos. Então, saber se é fácil identificar que a revista possui patrocinadores também era uma preocupação a ser investigada na consulta. O grau 4 foi o que mais recebeu respostas, sendo que o grau 1 foi o que recebeu na sequência mais respostas. Acreditamos ser preciso emitir um editorial, ou um espaço no qual conste um agradecimento e alerta aos leitores de que existem empresas parceiras da revista, as quais sempre a ajudaram. Outra sugestão seria a inclusão das logomarcas ou logotipos das empresas parceiras em espaço próprio reduzido em outros documentos do periódico, tais como relatórios de avaliação de artigos, como no caso dos autores.

Finalmente, como última pergunta feita na sequência gradual de impressões dos autores em relação à imagem da revista e seu sítio eletrônico, realizamos a seguinte pergunta. A qualidade geral da revista Terre Didatica é grande? A maioria das respostas foi dada ao grau 5 , recebendo também 
em segundo o grau 4 e menor valor o grau 3 (Fig. 2e).

Utilizamos a mesma metodologia de questionamento acima, por meio de gradação de 1 a 5, para obtermos informações sobre as impressões dos autores em relação ao processo de avaliação dos artigos (Fig. 3).

Foram realizados seis questionamentos em relação ao processo de avaliação. O primeiro questionamento foi se o autor acredita que foi bem orientado em relação às etapas do processo de avaliação. Recebemos respostas no grau 2 a 5 , sendo que a tendência foi de respostas concentradas no grau 5 . O questionamento seguinte feito aos autores foi se a comunicação por e-mail facilitou a submissão e revisão dos manuscritos. Novamente recebemos respostas nos graus de 2 a 5 , sendo que obtivemos maior concentração no grau 5 (Fig. 3). Em relação a clareza, isenção e se as avaliações dos revisores contribuíram para os manuscritos, os autores gradaram de 3 a 5, sendo que a maciça maioria acredita que o grau 5 foi o mais adequado como resposta. $\mathrm{O}$ quesito proposto em relação à profundidade dada pelos revisores aos manuscritos foi a que mais recebeu respostas no grau 5. Interessante salientar que os demais graus também receberam respostas, mas em muito menor valor que o grau 5. Outro quesito que também recebeu respostas em todos os graus propostos foi em relação à adequação do prazo entre a submissão, avaliação e publicação. A maioria acredita ser adequado o prazo, pois aponta o grau 5 como o mais adequado, mas o grau 4 e 3 também receberam quantidade considerável de respostas. Por fim, queríamos saber se os autores acreditam que em caso de haver discordância entre o autor e revisor em relação à avaliação dos manuscritos, eles foram ouvidos e considerados. Foi a única resposta em que alguns autores não opinaram. Recebemos a grande maioria de respostas no grau 5 , e a concentração das respostas ficou nos graus de 3 a 4, e nenhuma resposta nos graus 1 e 2 . A sequência nos leva a crer que os autores acreditam na revisão feita por pares por Terrce Didatica, que consideramos altamente qualificada. Acreditam os autores que o processo é justo, correto e célere. É importante salientar
Análise do processo de avaliação

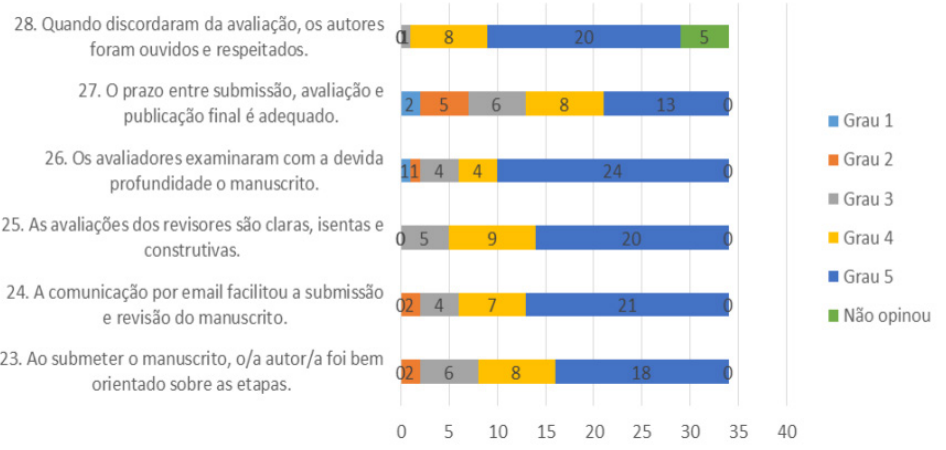

Análise do processo de avaliação e avaliação de artigos

que a pesquisa foi feita junto a autores os quais tiveram artigos publicados e junto àqueles que não tiveram idêntico resultado, e mesmo assim tivemos as respostas acima.

Na sequência realizamos três perguntas (Fig. 4), sendo uma em relação a divulgação da revista e duas opinativas sobre a periodicidade da publicação e adequação atual do seu perfil, do sítio na internet e do padrão de publicação; as respostas possíveis eram sim, não ou não opinar.

A primeira questão era se o autor acredita que deve se manter inalterado o perfil, sítio web e padrão de publicação. Do total, 20 autores responderam que sim e 14 autores responderam que não. A proximidade do número de respostas nos leva a crer que este grupo acredita que a revista poderia se beneficiar com uma melhora em seu padrão de publicação, acreditamos principalmente no seu sítio eletrônico, o qual foi lembrando com certa frequência no espaço destinado a sugestões. Duas questões da pesquisa tiveram respostas exatamente divididas entre as respostas possíveis, sendo a primeira o quesito sexo do entrevistado, e a segunda foi a pergunta em tela, a qual foi, se a revista pre-

\section{Conclusão Opinativa}

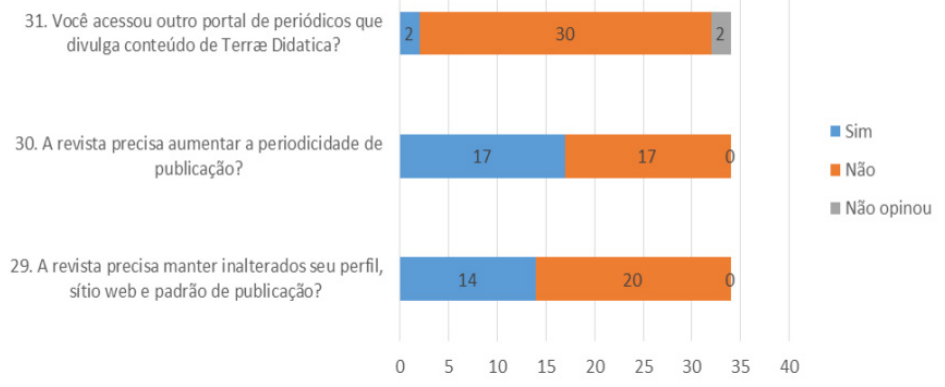

Figura 4. Sequência de perguntas opinativas junto aos autores 
cisa aumentar a periodicidade de publicação. 50\% respondeu que sim e $50 \%$ respondeu não. A derradeira questão da última sequência foi se os autores acessaram outro portal de periódicos que divulga o conteúdo da revista (Fig. 30). Encontramos que a esmagadora maioria declinou que não, sendo que apenas duas respostas foram atribuídas ao sim e dois autores não opinaram.

Ficamos curiosos sobre os portais referidos por dois autores que declinaram ter acessado outros portais que divulgam conteúdos de Terre Didatica. Um autor declinou que acessou conteúdo da revista no portal da PPeGeo, e outro no portal da USP; acreditamos que o segundo autor também quis relacionar como resposta a plataforma da PPeGeo.

Como última questão, perguntamos aos autores se possuíam sugestões, críticas ou outras informações que gostaria de deixar para Terree Didatica. Tivemos o mais variado leque de sugestões, algumas como a reformulação do sítio eletrônico para ganhar maior apelo visual, assim como disponibilizar uma ferramenta de pesquisa dentro do próprio sítio para facilitar a busca de arquivos ou assuntos, outras como a aquisição do DOI, ao qual a revista já aderiu. Tivemos também elogios e palavras de incentivo para que o periódico continue em sua jornada.

\section{Revisores}

Outro grupo qual importante na pesquisa foi o de revisores de Terre Didatica, não somente para recolher informações sobre o grupo específico, assim como suas impressões e demais dados, mas também para confrontar as visões dos revisores com as dos autores; portanto, propusemos questões que se complementam quando coletadas respostas de ambos os grupos. O intuito é o da melhoria constante. De acordo com os arquivos de Terre Didatica, a revista conta com um total de 70 revisores capacitados para atuar como consultores, com a função de revisar manuscritos submetidos à impressão. $100 \%$ dos revisores são ligados de alguma forma com uma instituição de ensino superior. Em relação à moradia $84 \%$ moram no Brasil e $16 \%$ são estrangeiros (Fig. 5a).

Em relação aos integrantes das arcadas da Unicamp, em específico o Instituto de Geociências, encontramos a seguinte situação, $21 \%$ são da Universidade Estadual de Campinas e 79\% de outras instituições de ensino (Fig. 5b). Deste ponto em diante nos ateremos aos resultados obtidos nos formulários de pesquisa enviados por correio eletrôni- co. A pergunta comum aos questionários aplicados, em todos os grupos, foi se o pesquisado autorizaria ter sua identidade revelada (Fig. 5c). Obtivemos o resultado de que $82 \%$ dos entrevistados autorizam a divulgação, enquanto $18 \%$ não autorizam. Precisávamos conhecer quem são os revisores, e para isso iniciamos a descoberta por meio da pergunta de nomes. Em seguida a pergunta eleita foi sobre local de moradia (Fig. 5d). Quase a metade dos revisores que responderam à pesquisa é de São Paulo, ou seja, $46 \%$. Na sequência vemos os cariocas com $18 \%$ do total. Com 7\% temos revisores do Paraná e Minas Gerais. Com o mesmo percentual temos revisores da Argentina. Dentre revisores internacionais temos com $4 \%$ integrantes deste grupo com moradia na Espanha e Portugal. Voltando ao Brasil e com pequeno percentual, $3 \%$ residem em Minas Gerais. $7 \%$ dos revisores não declinaram onde residem. Perguntamos aos revisores o seu sexo (Fig. 5e). Encontramos $68 \%$ do sexo masculino e $32 \%$ do sexo feminino.

Queríamos saber também as idades e encontramos concentração $59 \%$ de revisores com idades entre 51 a 60 anos (Fig. 5f). Logo após vem o grupo de revisores com idades entre 41 a 50 anos, com $15 \%$; com $11 \%$ o grupo de 61 a 70 anos, $8 \%$ de revisores com 31 a 40 anos e finalmente $7 \%$ dos pesquisados não indicou sua idade (Fig. 5f). O grande percentual encontrado na faixa dos 51 a 60 anos parece ser devido à preocupação com a qualidade, pois é necessário elevado grau acadêmico, assim como é relevante haver experiência prática. A escolaridade foi outro item pesquisado. A concentração se mostrou em revisores Doutores, $43 \%$. $22 \%$ indicaram ser graduados, $22 \%$ pós-graduados e $14 \%$ possuem pós doutorado (Fig. $5 \mathrm{~g}$ ). Para poder continuar a criar o perfil de nossos revisores, precisávamos saber onde trabalham (Fig. 5h). Praticamente todos os revisores trabalham em universidades públicas, totalizando o percentual de $96 \%$. Apenas um revisor se indicou como sendo autônomo. Sabendo o local onde trabalham, passamos à pergunta do cargo que ocupam. Novamente encontramos uma tendência entre os pesquisados. $86 \%$ são professores, $11 \%$ se disseram Diretores e 3\% são técnicos (Fig. 5i). O gráfico também demonstra a preocupação da revista de dispor de revisores experientes. Sendo o grupo composto por profissionais que se dedicam a vida acadêmica, perguntamos se possuem currículo indexado na plataforma Lattes: $86 \%$ dos pesquisados possuem currículos na plataforma Lattes, $14 \%$ não possuem. Passamos neste 


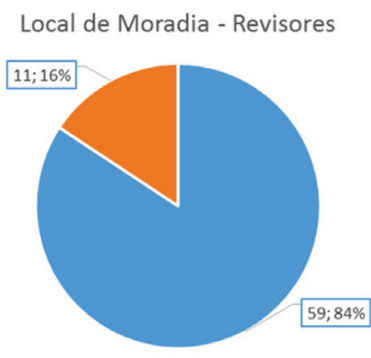

- Brasil - Exterior

Instituição de Ensino

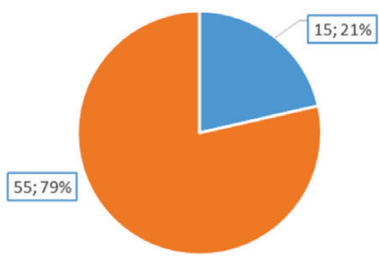

- Membros Unicamp - Externos

Você concorda em ter sua identidade revelada?
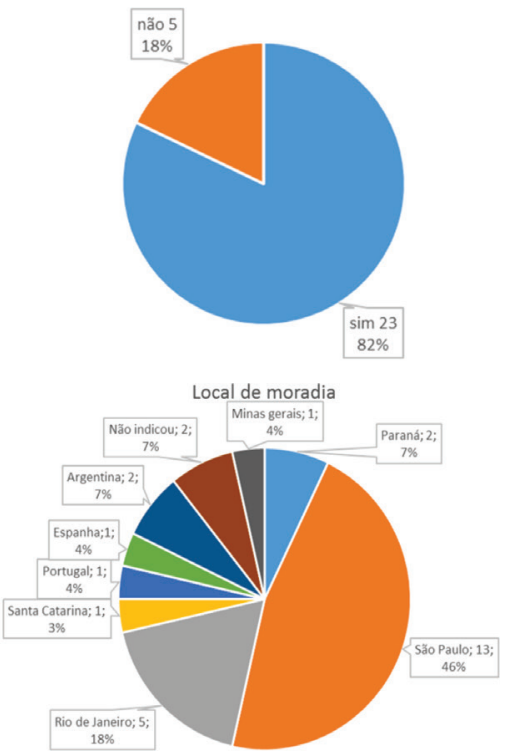

Sexo

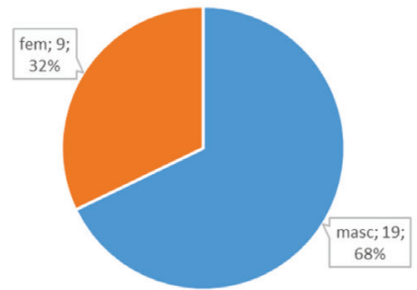

A
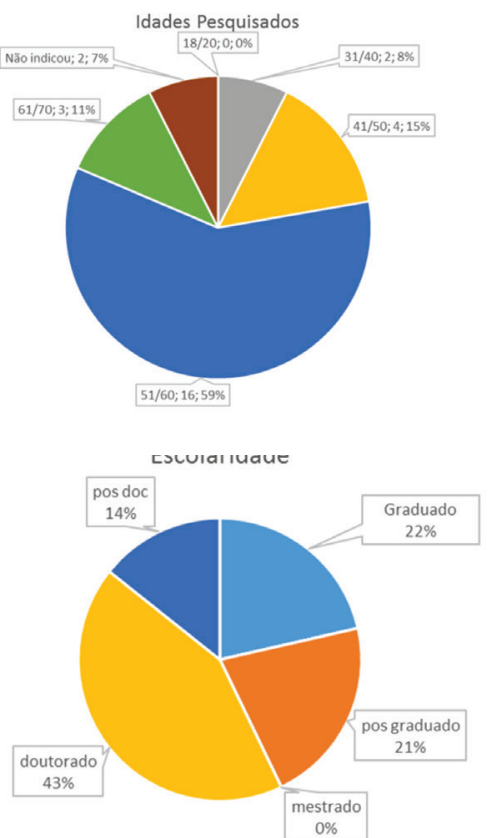

G

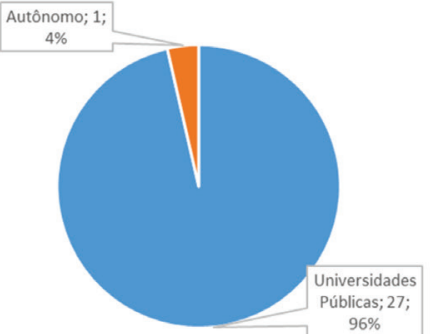

$\mathrm{H}$
Profissão/função que desempenha

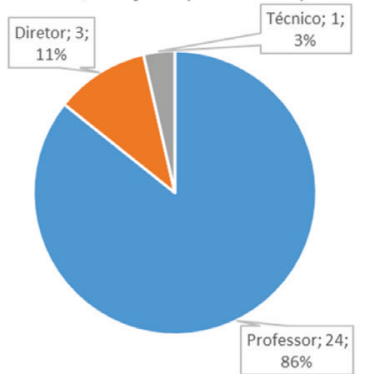

Como ficou sabendo da TD

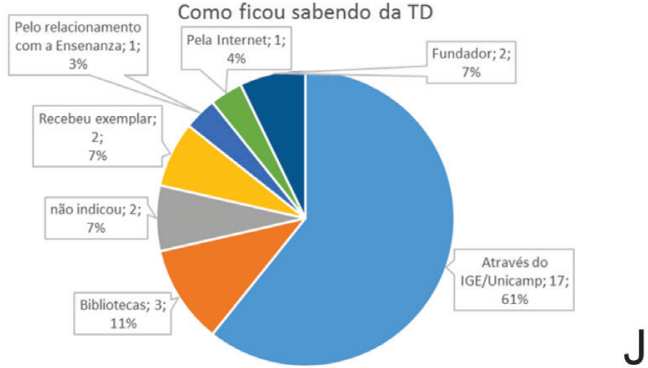

$E$

Figura 5. Respostas dos Revisores ao questionário, parte A: (a) percentuais de revisores que moram no Brasil ou no Exterior; (b) percentuais de revisores que integram a Unicamp e demais; (c) percentuais de revisores que aceitam ter suas identidades reveladas; (d) locais de moradia dos revisores; (e) percentuais sobre sexo dos revisores; (f) percentuais das idades dos entrevistados; (g) nível de escolaridade dos revisores; (h) empresas em que trabalham os revisores; (i) a quais funções/profissões se dedicam os revisores; (j) percentuais sobre como os revisores souberam da existência de TD 
momento para a relação do revisor com a revista. Começamos querendo conhecer como os revisores ficaram sabendo da existência de Terra Didatica. Mais da metade, $61 \%$, declinaram que conheceram a revista por meio de algum relacionamento com o IG Unicamp (Fig. 5j). Outros 11\% responderam que foi por meio de exemplares que tiveram contato em bibliotecas de suas instituições de ensino. $7 \%$ responderam ter conhecido por meio de um dos fundadores da revista e, no mesmo percentual, declinaram que receberam um exemplar. $4 \%$ indicaram que souberam da revista pela internet; no percentual de $3 \%$, apresentaram que souberam por meio da publicação Ensenanza de las Ciências de la Tierra. 7\% não indicaram como souberam da revista. Isso nos deixa clara a dificuldade de fazer divulgação da revista de forma eficiente. Este item deve ter maior atenção, buscando a indexação em plataformas de Acesso Livre, assim como inclusão em redes sociais e também em congressos e feiras, tirando um pouco do peso das costas dos editores da revista, os quais em toda chance distribuem o periódico para seus alunos e colegas.

Perguntamos então o que os revisores acham do processo de avaliação editorial da revista, do qual participaram (Fig. 6). 82\% acreditam que o processo de avaliação editorial é eficiente. Apenas 4\% indicaram que o processo é deficitário ou demorado e confuso. 3\% indicou neste campo, ao invés de dar sugestões, que o procedimento de revisão deveria ser incluso em plataforma eletrônica. 7\% dos pesquisados não apontaram o que acham do processo. Mais uma vez vemos alto índice de aprovação no processo de avaliação, mas como 3\% indicaram, a criação de um procedimento eletrônico de revisão e acompanhamento se torna premente, principalmente se almejamos a indexação em outras plataformas de Acesso Livre.

Quanto aos motivos que levaram os pesquisados a aceitar ser revisores, o interesse pessoal atingiu $50 \%$ dos pesquisados. Na sequência, 23\% dos revisores apontaram a importância da revista como sendo a principal causa de terem aceito colaborar com Terre Didatica. 15\% indicaram o convite como sendo única motivação. A qualidade editorial recebeu $8 \%$ das indicações e finalmente $4 \%$ dos pesquisados relacionaram que a importância dos temas apontados seria o motivo para terem aceito ser revisores. Como vimos junto aos autores, os revisores também deixaram em segundo plano a importância da revista. Fato este que demanda atenção como já relacionado. Em relação à quantidade de artigos avaliados, a maioria dos revisores, 45\%, indicou ter avaliado mais de dois artigos (Fig. 6c), sendo que $26 \%$ dos pesquisados responderam que avaliaram dois artigos. $22 \%$ avaliaram apenas um e $7 \%$ não se recordam quantos textos avaliaram.

Perguntamos então, se os revisores divulgaram a revista, para quem e por meio de qual canal de comunicação (Fig. 6d). Obtivemos as seguintes respostas: todos os revisores apontaram ter divulgado a revista. Sendo que 38\% destes revisores relacionaram que falaram sobre a revista com colegas, alunos e também indicaram à biblioteca de suas instituições. $11 \%$ indicou que comentaram sobre a revista com sua rede de contatos pessoais, $10 \%$ para alunos e colegas, e no mesmo percentual apenas para alunos, em percentual menor, $7 \%$, indicaram a revista para colegas e a biblioteca de suas instituições e $24 \%$ não declinaram as respostas. Dos revisores que divulgaram a revista, $46 \%$ não indicaram o meio que utilizaram para fazê-lo. 18\% utilizaram o e-mail como canal, e idêntico percentual relacionou que repassou a revista impressa as pessoas que comentou sobre a publicação e $9 \%$ relacionam o boca a boca como meio, assim como, no mesmo percentual, declinam que emprestaram a revista e indicaram o site como meio de comunicação eleito para a divulgação do periódico. Também vemos a importância da manutenção do formato eletrônico da revista, pois como um veículo de fácil acesso e livre de custos, temos a facilitação da divulgação do periódico. Perguntamos então se os revisores continuam acompanhando a revista. Dentre as respostas, $89 \%$ dos pesquisados responderam que sim, continuam acompanhando a revista. $11 \%$ declinou que não. Dentre os que continuam a acompanhar o periódico, perguntamos então o meio que utilizam para tanto. $40 \%$ dos pesquisados responderam que utilizam tanto a internet quanto a revista impressa como forma de se manterem atualizados sobre o conteúdo de Terra Didatica. Em proporção de $20 \%$, os revisores responderam que continuam acompanhando a revista, ou por meio do seu sítio eletrônico, ou por meio da mídia impressa. $\mathrm{Na}$ mesma proporção, ou seja, $20 \%$, os pesquisados não responderam por qual meio acompanham a revista. Acreditamos que a tendência ampliar-se-á quando for implementada a revista em outras plataforma na internet, aumentando ainda mais sua visualização e trazendo outros benefícios.

Utilizando a mesma sistemática realizada junto aos autores (Fig. 6e), perguntamos de forma fechada, admitindo respostas somente pelas gradações 


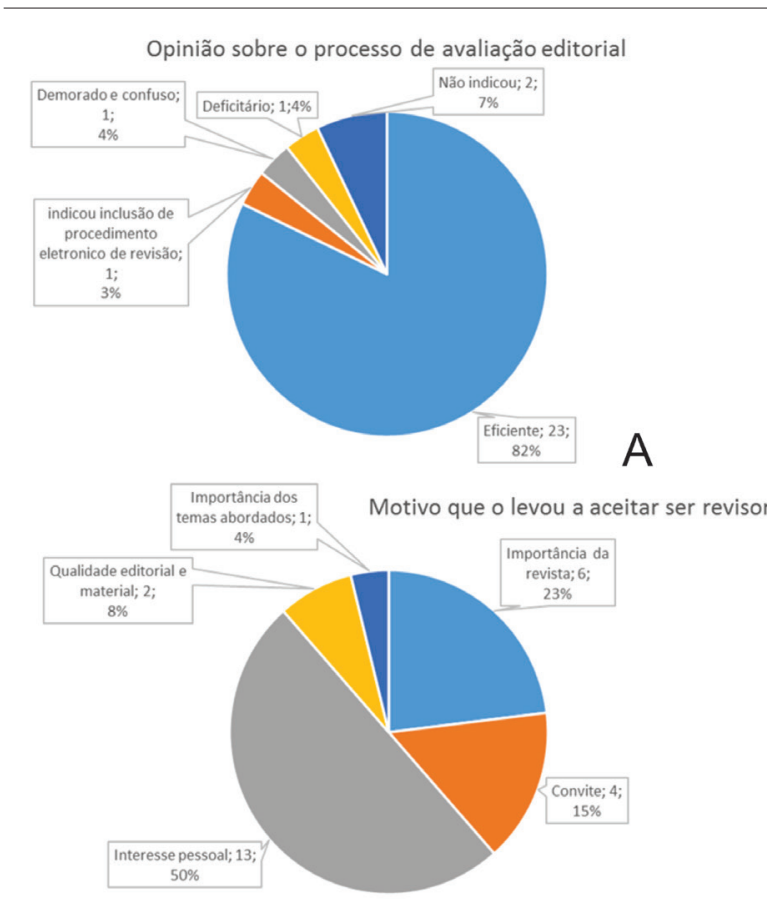

Quantos artigo avaliou para a revista?

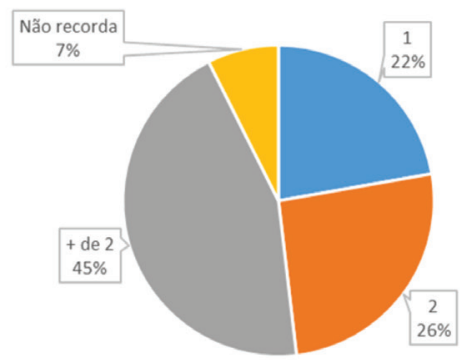

C

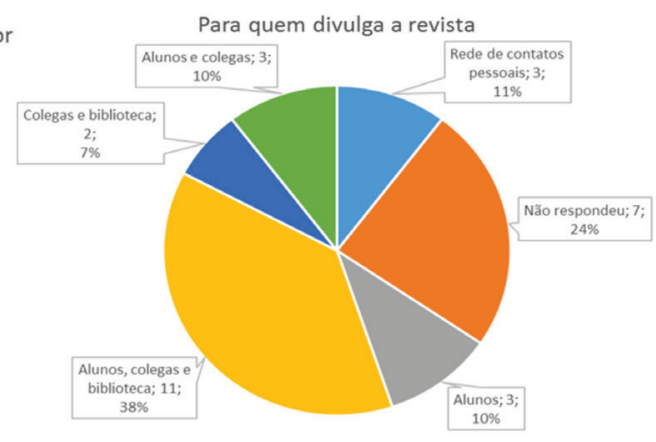

B

D

\section{Análise do sítio eletrônico do periódico e sua imagem junto aos revisores}

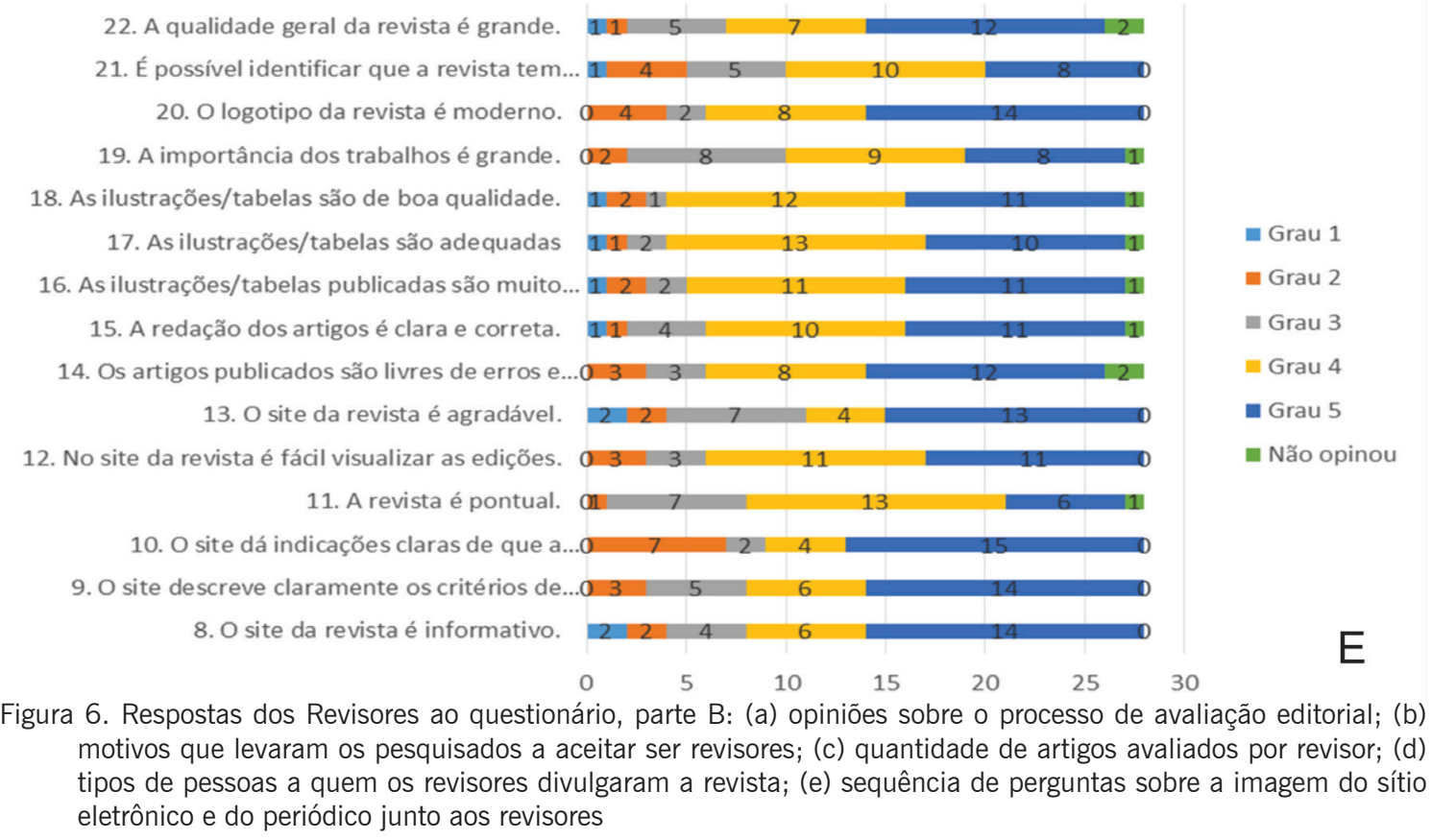

de 1 a 5, representando os graus de concordância dos revisores com as perguntas, sendo 1 o grau que menos representa o que pensam os revisores e 5 o que mais se aproxima ao que pensam. Foi realizada uma série de 15 perguntas sobre o sítio eletrônico de Terre Didatica e sua imagem, quais respostas se encontram no gráfico da Figura 6e. A primeira pergunta foi em relação se o sítio eletrônico é claro, apropriado e informativo, se expõe bem seu conteúdo. Obtivemos respostas em todos os graus, sendo que o grau 5 foi o mais escolhido entre os pesquisados, decaindo as escolhas no grau 4 , depois 
3 e assim sucessivamente. A próxima questão foi de se o site da revista descreve claramente os critérios de submissão e público-alvo. Nesta questão obtivemos respostas começando do grau 2 , sendo que novamente o grau 5 foi o mais escolhido entre os pesquisados. Colocamos então se o site dá indicações claras de que a submissão é inteiramente eletrônica. Nesta questão o segundo mais escolhido foi o grau 2 e o mais escolhido foi o grau 5 . Temos então resultados apresentados em sua maioria no grau 5, mas o grau 2 também recebeu um número considerável de respostas. Como na anterior o grau 1 não foi lembrado pelos pesquisados. Queríamos saber então se os revisores acreditam que a revista é pontual, se respeita a pontualidade estabelecida. Neste quesito, os revisores acreditam que a revista é pontual, mas atribuíram em sua maioria o grau 4, ficando o grau $3 \mathrm{em}$ segundo e o grau $5 \mathrm{em}$ terceiro.

No site da revista é fácil visualizar as edições: a atual e as anteriores. Quando isto posto aos nossos revisores, estes indicaram que sim, obtendo o grau 5 e 4 o mesmo número de respostas. Os graus 3 e 2 também pontuaram, mas em reduzida quantidade. Questionamos então se o site da revista é agradável e visualmente adequado. Os pesquisados em sua maioria relacionaram o grau 5 , sendo o grau 3 o segundo a obter mais respostas. Todos os outros graus receberam, em menor valor, respostas. Colocamos então se os artigos publicados são bem organizados e isentos de erros e incorreções. Os graus 5 e 4 foram os que mais foram indicados como sendo adequados, tendo o 5 como o mais eleito. Queríamos saber, também, se os revisores achavam se a redação dos artigos é clara, com gramática e sintaxe corretas. Obtivemos maior concentração de respostas nos graus 4 e 5 , sendo este último o mais escolhido. Na questão os graus aqui apontados tiveram quase o mesmo número de respostas, sendo que os demais graus também foram apontados, ma em menor número de vezes.

Passamos então para uma sequência de assertivas em relação a tabelas e ilustrações publicadas nos artigos; a primeira foi se as ilustrações/tabelas publicadas são muito úteis e indispensáveis. Novamente os graus 4 e 5 foram os que mais obtiveram respostas, e neste caso em específico em número exatamente igual. Sendo que os outros graus receberam respostas, proporcionalmente muito mais baixas que os dois primeiros apontados. Relacionamos então se as ilustrações/tabelas possuem adequado nível de conteúdo e informação. O grau 4 foi o que mais obteve respostas, sendo que o grau 5 ficou como a segunda mais escolhida como resposta. Os demais graus também obtiveram respostas, mas ao todo foram em número reduzido (Fig. 6e). Questionamos se as ilustrações e tabelas possuem boa qualidade visual e legibilidade. Nesta também o grau 4 foi o mais indicado, seguido do grau 5. Diferença encontrada entre a quantidade de respostas relacionadas em ambos os graus foi pequena. E mais uma vez os demais graus também obtiveram poucas respostas. Com estas, encerramos o levantamento de impressões dos revisores sobre as ilustrações e tabelas publicadas em Terre Didatica. Passamos ao levantamento de impressões sobre a importância dos artigos publicados e questionamos se a importância geral dos trabalhos publicados é grande. Obtivemos respostas pulverizadas, em mesma quantidade, distribuídas entre os graus 3,4 e 5 . O grau 2 obteve poucas respostas e o grau 1 , nenhuma.

Sobre o aspecto visual, perguntamos se o logotipo da revista é moderno, de boa qualidade visual e legível. Observamos alta concentração de respostas no grau 5, e em segundo lugar o grau 4, praticamente com a metade da quantidade de respostas do primeiro grau apontado (Fig. 6e). Os graus 3 e 2 receberam poucas respostas e o grau 1 nenhuma. Como para os autores, assim como para os leitores, perguntamos se é possível identificar que a revista possui patrocinadores, pelos mesmos motivos já aduzidos. Novamente, como em outros questionamentos, obtivemos quantidade de respostas maior no grau 4 , seguido do grau 5 , sendo que proporcionalmente as respostas foram quase em mesmo peso, em ambos graus. Os demais graus também receberam respostas, em menor valor. Sendo que tais respostas somadas as respostas dos autores sobre mesma questão nos leva a concluir que seria salutar uma ampliação nos espaços para inclusão de logomarcas e logotipos dos patrocinadores.

Derradeiro foi o questionamento se a qualidade geral da revista Terre Didatica é grande. Seguindo a tendência de todos os questionamentos nesta série, também obtivemos o maior número de respostas no grau 5 , sendo que os graus 4 e 3 obtiveram proporcionalmente e de forma equânime, a metade da quantidade do grau 5 e os graus 2 e 1, obtiveram apenas um apontamento cada.

Na sequência, passamos a uma série de seis questões que foram elaboradas para medir as impressões dos revisores em relação ao processo de avaliação (Fig. 7). A série foi apresentada aos pesquisados da mesma forma que na série acima, 
ou seja, as respostas foram atribuídas na foram de eleição de graus, variando de 1 a 5 .

Salientamos que, nesta sequência, a quantidade de revisores que se eximiram em responder determinadas assertivas foi maior que em outras séries e também em outros grupos. Acreditamos que isso ocorreu por uma questão de idoneidade dos

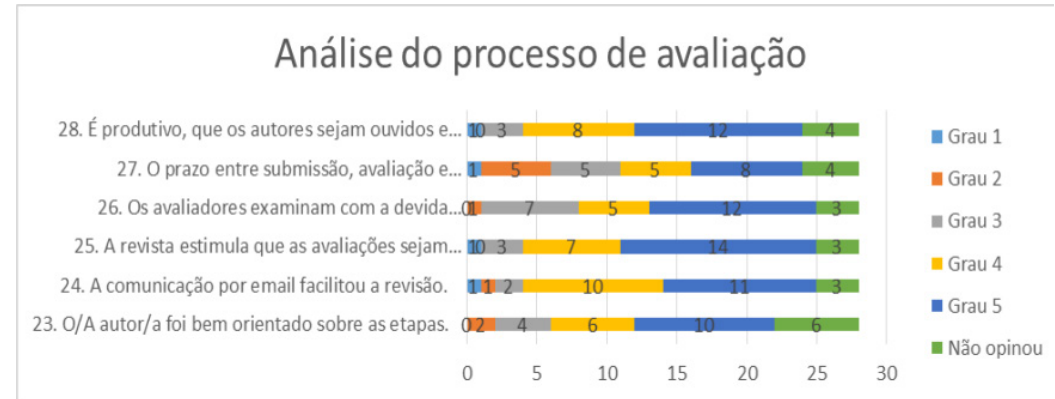

Figura 7. Sequência de perguntas referentes aos processos de avaliação dos artigos junto aos revisores revisores, os quais se abstiveram das questões as quais podiam ser tidas como um autoelogio. Passando as questões e seus resultados, ao submeter o manuscrito, o/a autor/a foi bem orientado sobre etapas. A qualidade atribuída à avaliação foi o primeiro questionamento que realizamos. O questionamento foi o que os revisores mais deixaram de responder: os graus de 2 a 5 receberam respostas e a concentração maior ficou no grau 5 , vindo o grau 4 na sequência, e logo atrás o 3 e finalmente o grau 2. Perguntamos então se os revisores acreditam se a comunicação por e-mail junto aos autores foi um facilitador. Os graus 5 e 4, respectivamente, receberam quase a mesma quantidade de respostas, seguidos pelos graus 3, 2 e 1 com pouquíssimas respostas. Mesmo com esse resultado, o gráfico nos demonstra que uma alteração na forma de comunicação utilizada de revisão e acompanhamento, como já dito, é ululante entre os entrevistados.

Questionamos se os revisores pensam que a revista estimula avaliações claras, isentas e construtivas. A grande maioria acredita que sim, pois recebemos grande quantidade de respostas no grau 5, ficando o grau subsequente com metade da quantidade de respostas recebidas nos outros graus acima (Fig. 7). Perguntamos se foi dada a profundidade devida nas avaliações dos manuscritos apresentados aos avaliadores. Os graus 5 e 3 foram os que mais receberam respostas, sendo que o grau 5 foi o grau mais lembrado como respostas pelos pesquisados. O grau 4 também recebeu um número significativo de respostas, em valores próximos ao grau 3. O grau 2 recebeu uma resposta, sendo que o grau 1 não recebeu resposta.

Em relação a prazos entre submissão, avaliação e publicação, perguntamos se os pesquisados acreditam que esses são adequados. A questão obteve uma pulverização em relação às respostas, pois os graus 2, 3 e 4 receberam o mesmo número, sendo que o grau 5 foi o mais escolhido, mas por uma diferença pequena em relação aos graus anteriores. O grau 1 também foi relacionado, mas apenas uma vez. 4 pesquisados se abstiveram de resposta.

Queríamos ouvir se os revisores acreditam se é produtivo ouvir e respeitar os autores no momento da avaliação. Novamente o grau 5 foi o mais relacionado como resposta, sendo que o grau 4 também recebeu número considerável de respostas. O grau 3 obteve poucas, e o grau 1 recebeu apenas uma resposta. O grau 2 não foi escolhido pelos revisores e interessante salientar que quatro pesquisados não declinaram opinião sobre o assunto.

Em sequência, fizemos três perguntas (Fig. 8). A primeira foi se o revisor acredita que a revista precisa manter inalterados seu perfil, sítio na web e padrão de publicação. Neste quesito o sim prevaleceu com diferença relativamente baixa em relação ao não, $53,57 \%$ contra $42,85 \%$. Um revisor não respondeu, ou seja, 3,58\%. O que nos deixa transparecer mais uma vez que, como aconteceu com os autores, uma reformulação do sítio eletrônico também será benéfica. Novamente, verifica-se que a recomendação está presente nas sugestões dadas ao final do questionário. A segunda pergunta da sequência foi se a revista precisa aumentar sua periodicidade de publicação. 10,71\% dos pesquisados não responderam, sendo que o não recebeu $64,28 \%$ das respostas. O sim recebeu $25 \%$.

Com o intuito de saber se os revisores utilizam outras plataformas de acesso de conteúdos nas quais constam os artigos de Terre Didatica. 78,57\% dos pesquisados disseram que não acessaram em outros portais, $17,85 \%$ disseram que sim. 3,58\% dos pesquisados não responderam a esta questão. Tal tendência mudará quando ampliada a indexação do periódico junto a outras plataformas.

Dos pesquisados os quais disseram que consultaram o conteúdo do periódico por meio de outros portais, $40 \%$ a acessaram ou pela plataforma PPeGeo, ou pela FAPESP. 20\% não opinaram em qual 
outra plataforma na internet teriam visto o conteúdo do período. Outro item que foi relacionado em todos os três grupos pesquisados foi o pedido de sugestões, críticas ou outras informações; tal como no caso dos autores, foram feitas sugestões de melhoria do sítio eletrônico no aspecto gráfico e no implemento de ferramenta de busca de artigos e temas, assim como sistema de revisão eletrônico para acompanhamento dinâmico por todos os envolvidos. Outras sugestões foram de inclusão do DOI, como já dito, feito anteriormente, assim como inclusão em outras plataformas de Acesso Livre. Uma constante também vista foi o agradecimento pela existência do periódico.

\section{Leitores}

Passaremos agora ao lançamento dos dados obtidos da pesquisa junto aos leitores da revista Terræ Didatica (Figs. 9 a 13). A pesquisa é importante, pois a plena recepção do período por seu público-alvo é a razão de ser da própria revista, pois, como qualquer canal de comunicação, não haveria porquê existir Terrce Didatica se não fosse pelo seu público. A princípio foi questionado se os pesquisados concordariam em ter suas identidades reveladas (Fig. 9a). $67 \%$ dos pesquisados responderam que sim e $33 \%$ responderam que não.

Como nos caso dos demais grupos, iniciamos a pesquisa com o intuito de saber se os Leitores pesquisados autorizam ter a identidade revelada: $67 \%$ contra 33\% (Fig. 9a). A questão seguinte foi para conhecer o perfil dos pesquisados (Fig. 9b): em relação ao local de moradia, que a grande maioria dos leitores pesquisados reside no Estado de São Paulo, seguido pelo Rio de Janeiro com 11\%; em mesmo percentual temos leitores no Paraná. 8\% dos leitores estão localizados no Rio Grande do Sul, 5\% em locais diversos de Portugal, 3\% em Pernambuco. Com 2\% temos os estados do Pará, Mato Grosso, Goiás, Santa Catarina, Bahia e Rio Grande do Norte. 7\% não declinou seu local de moradia. Novamente, como acontecera com Autores, vimos que a revista precisa de um reforço de divulgação nos estados do Centro-Oeste, Norte e Nordeste, não sendo prejudicial também a ampliação da divulgação em outras regiões e quiçá países. Para isso a internet é importante aliado, e nesta questão, de ampliação de divulgação junto aos lei- tores, acreditamos que o advento do uso do Google Adwords, um sistema de divulgação paga junto ao portal do Google de baixo custo não será de todo mal. A questão contida na Figura 9c queria saber o sexo do público pesquisado. Descobrimos que $72 \%$ dos pesquisados são do sexo masculino e $28 \%$ do sexo feminino. A maioria dos pesquisados (Fig. 9d) possui idades entre 51 a 60 anos, seguida pela faixa etária de 41 a 50 anos. Com $8 \%$ encontramos as faixas entre 61 a 70 anos e 21 a 30 anos. $2 \%$ foi o percentual encontrado nas faixas de 21 a 30 anos e 71 anos acima. Não encontramos leitores na faixa dos 18 aos 20 anos. 30\% dos pesquisados não declinaram a idade.

Quanto à escolaridade, 35\% dos leitores pesquisados possuem doutorado (Fig. 9e). 23\% dos leitores declinaram que possuem pós-graduação, $12 \%$ mestrado ou pós-doutorado e $18 \%$ se disseram com graduação completa. Tal resposta nos dá um sinal de alerta, pois não vemos a adesão de leitores com graduação incompleta ou de outros níveis de ensino. Para identificar a localização exata dos pesquisados, em complemento à questão em relação à moradia, perguntamos o local onde trabalham (Fig. 9f). A grande maioria, $72 \%$ indicou que trabalha em instituições de ensino superior pública, ou Universidades Públicas. O restante ficou dividido da seguinte maneira: $8 \%$ Petrobras, 3\% são aposentados, em mesmos 2\%, Centro de Tecnologia Mineral, CDTN/CNEM, universidades privadas, Marinha do Brasil, AFESBJ - instituição de ensino médio, Instituto Sauber, prefeitura e, com 1\% cada, iniciativa privada, ETEC e CEMADEM. Novamente faltam os estudantes!

Queríamos saber então, nas instituições acima eleitas, qual o cargo que ocupam os pesquisados 

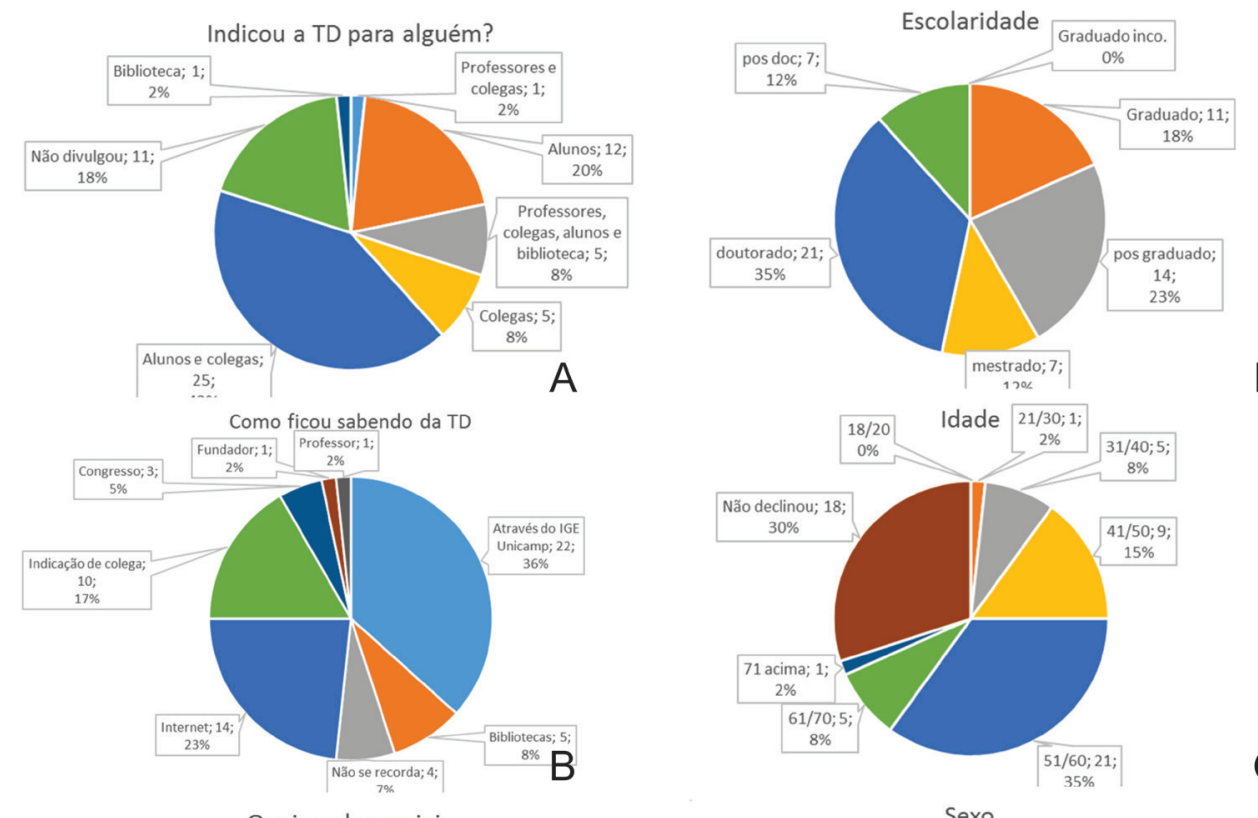

$\mathrm{F}$

Quais redes sociais
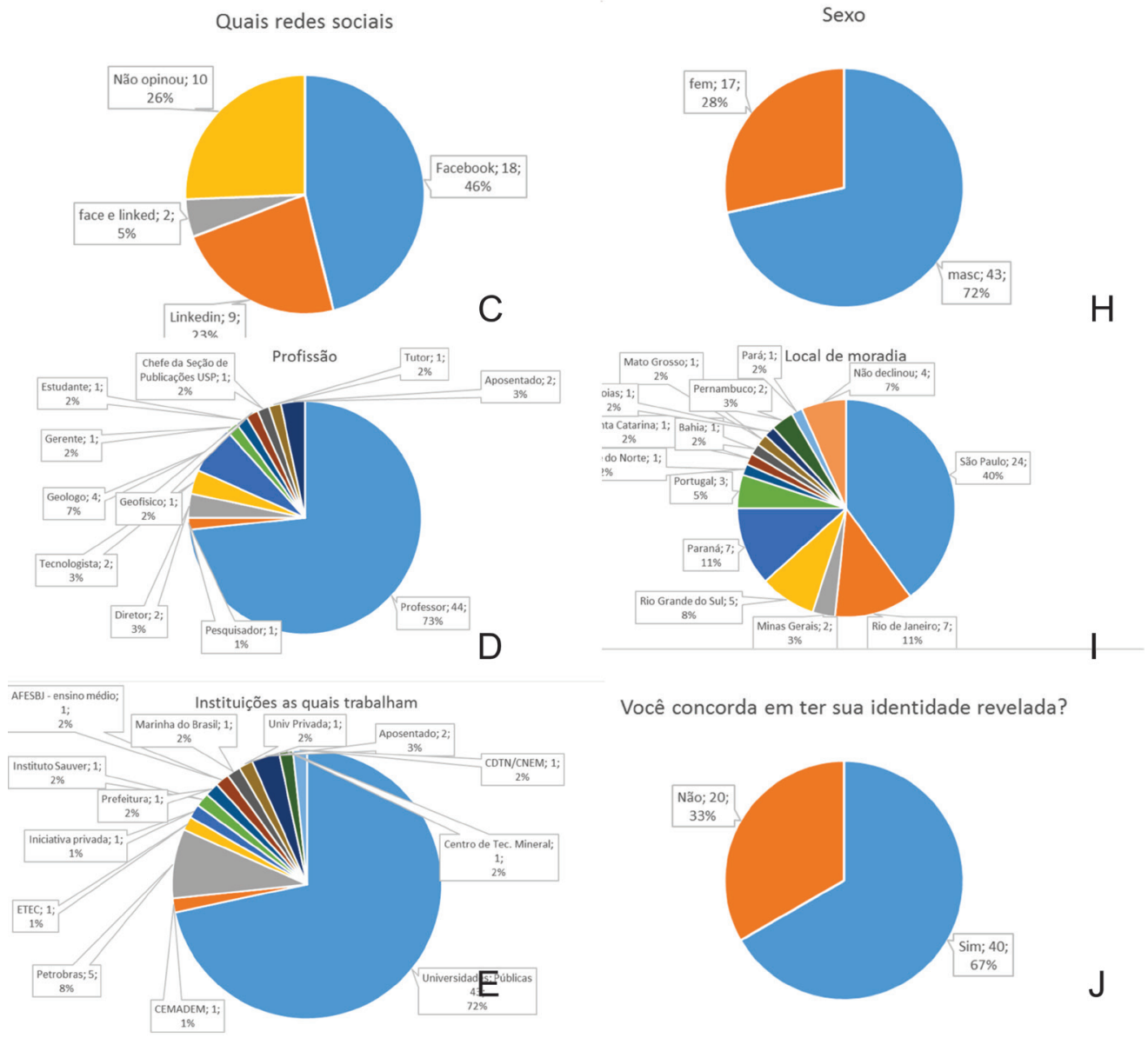

Você concorda em ter sua identidade revelada?

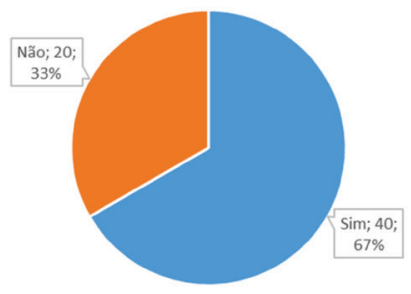

Figura 9. Respostas dos Leitores ao questionário, parte A: (a) percentual de leitores que concordam em ter suas identidades reveladas; (b) locais de moradia dos leitores; (c) percentuais de sexo masculino e feminino dos leitores pesquisados; (d) idades dos leitores pesquisados; (e) níveis de escolaridade dos leitores; (f) percentuais de instituições nas quais trabalham os leitores; (g) percentuais de profissões dos leitores; (h) percentuais de perfis em redes sociais dos leitores; (i) percentuais de formas pelas quais os leitores ficaram sabendo da revista; (j) percentuais de pessoas para quem os leitores indicaram a revista 
(Fig. 9g). 73\% indicaram que são professores, 7\% são geólogos, com $3 \%$ cada, aposentados, tecnologista e diretor. Com $2 \%$ cada encontramos, tutor, chefe de publicações da USP, estudante, gerente e geofísico. $1 \%$ indicou que é pesquisador. Continuando a explanar os resultados da pesquisa junto a leitores, observamos que a grande maioria é composta por acadêmicos; perguntamos se possuíam currículo na Plataforma Lattes. Assim podemos se necessário captar mais dados secundários. 82\% dos pesquisados indicaram que possuem currículo Lattes e 18\% restantes indicaram que não possuem. Sempre é desejável estar presente nos locais onde o público está, fornecendo-lhe conteúdo. Para tanto perguntamos se possuem perfis nas redes sociais, facebook e Linkedin. 66\% responderam que possuem perfil nas redes sociais eleitas. 34\% declinaram que não possuem. Portanto, se figurarmos TD nas redes sociais a divulgação terá maior pulverização em relação a conteúdo e maior visibilidade junto ao público-alvo. Identificamos que $66 \%$ dos pesquisados possuem perfis na internet, tendo sido mais relacionadas as redes facebook e Linkedin como as em que os pesquisados estão inseridos (Fig. 9h). A maioria $46 \%$ possui perfil no facebook, $23 \%$ está no Linkedin, $5 \%$ possuem perfis em ambos e $26 \%$ não opinou em qual rede social estão registrados. Para compreender qual o canal de comunicação que foi mais eficiente em relação de disseminação da revista dentre nosso público, perguntamos como o pesquisado ficou sabendo do periódico (Fig. 9i). $36 \%$ indicaram ter ficado sabendo por algum relacionamento que teve junto ao IG-Unicamp. 23\% apontaram ter conhecido o periódico em pesquisa na internet. $17 \%$ afirmaram ser devido a indicações de colegas. $8 \%$ conheceram por meio de exemplares nas bibliotecas de instituições de ensino das quais fazem parte. $7 \%$ não se recordam, $5 \%$ dos pesquisados tiveram primeiro contato com a revista em algum congresso o qual participou. Finalmente $2 \%$ relacionaram que conheceram a revista por meio de algum professor ou de um dos fundadores do periódico. Questionamos então se o pesquisado teria indicado a alguém a leitura de Terre Didatica (Fig. 9j). 42\% indicaram o periódico a alunos e colegas, $20 \%$ divulgaram apenas a alunos, $18 \%$ não divulgram a revista a ninguém, $8 \%$ divulgaram para colegas ou professores, colegas, alunos e biblioteca de suas instituições de ensino. $2 \%$ cada indicaram para suas bibliotecas ou professores e colegas. Dos pesquisados que responderam que haviam divulgado a revista a alguém, pedimos então para que declinassem quais canais haviam escolhido para tanto (Fig. 10a). O boca a boca foi o mais escolhido com $32 \%$, seguido pelo empréstimo da revista impressa com $22 \%$. 15\% indicaram via e-mail e $13 \%$ declinaram ter utilizado algum meio eletrônico (fórum, e-mail etc.) e também emprestaram a revista a alguém. 18\% não informaram o meio utilizado para divulgação da revista. Quando pedimos a alguém para que nos diga o quanto algo lhe é precioso, se torna mais fácil a tarefa de valoração quando atribuímos a isso uma quantia em espécie. Queríamos saber então o quão precioso aos nossos leitores pesquisados o é Terræ Didatica, por meio da pergunta de quanto pagariam pela revista (Fig. 10b). Informamos que a revista tem distribuição gratuita e assim permanecerá

Quase metade dos pesquisados, $44 \%$, indicaram que pagariam mais de $\mathrm{R} \$ 15,00$. Não muito abaixo, $40 \%$ dos pesquisados declinaram que pagariam de $\mathrm{R} \$ 5,00$ a $\mathrm{R} \$ 15,00$. $8 \%$, talvez por receio que venhamos a cobrar pela revista, não apontaram quanto pagariam. $5 \%$ disse que a revista deve manter-se gratuita para que possa ser amplamente divulgada, sendo assim não pagaria nenhum valor. $3 \%$ apontou outro valor.

Para verificar como funciona o relacionamento dos leitores pesquisados com a revista, fizemos uma sequência de 6 questões fechadas (Fig. 10c), nas quais as respostas possíveis foram: sim, não ou não opinar. Terre Didatica possui uma comunidade aberta no Linkedin. Gostaríamos de saber se os leitores a conheciam. 57 leitores, ou 95\%, não conheciam, sendo então que apenas 3, ou $5 \%$ conheciam. A próxima questão foi se os pesquisados gostariam de contar com uma comunidade no facebook. $62 \%$, ou 37 leitores pesquisados declinaram que gostariam de uma comunidade do periódico no facebook. 13 leitores, 21\%, disseram não à comunidade na tal rede social. 10 pesquisados, $17 \%$, não declinou resposta. Perguntamos então se o leitor gostaria de receber novidades da revista por e-mail, $88 \%, 53$ leitores disseram que sim, enquanto apenas $10 \%$, 6 pesquisados, não querem receber e-mail com novidades do periódico. 1 leitor não respondeu, $2 \%$ do total. A próxima pergunta foi se o leitor sabia que pode receber a revista em casa. 41 leitores, ou $68 \%$ do total declinou que não sabia, $32 \%$ disse que sabia, ou seja, 19 leitores já conheciam a informação. Aproveitamos então para perguntar se os leitores gostariam de receber Terre Didatica no endereço que melhor lhe convir, pagando para isso apenas o envio, $60 \%$, ou seja 36 leitores disseram 




\section{Contato com a TD}

9. Você continua acompanhando a revista?

8. Você gostaria de receber Terræ Didatica em sua casa pagando pelo envio?

7. Você sabia que pode receber Terræ Didatica em sua casa?

6. Você gostaria de receber novidades da Terræ Didatica por e-mail?

5. Você gostaria que existisse uma comunidade da Terræ Didatica no facebook?

4. Você conhece a comunidade do linkedın na Internet sobre a Terræ Didatica?

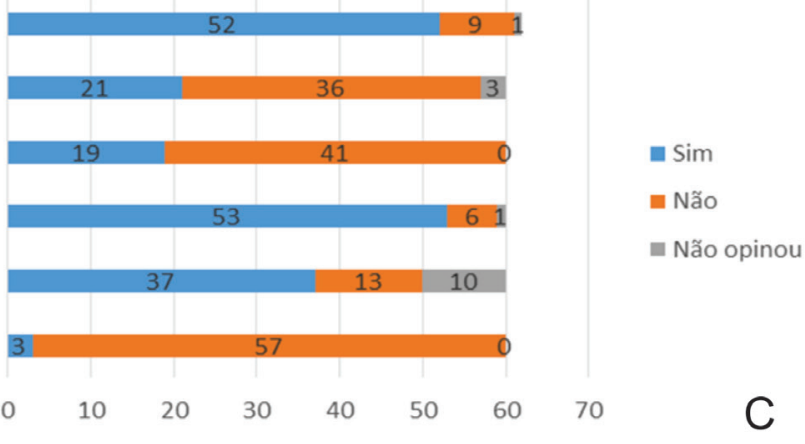

\section{Imagem da mídia impressa e sítio eletrônico junto aos leitores}

23. Você encontra facilmente a revista impressa.

22. A qualidade geral da revista é grande.

21. É possível identificar que a revista possui..

20. O logotipo da revista é moderno.

19. A importância geral dos trabalhos é grande.

18. As ilustrações/tabelas são de boa qualidade

17. As ilustrações/tabelas possuem adequado

16. As ilustrações/tabelas publicadas são úteis.

15. A redação dos artigos é clara.

14. Os artigos publicados são bem organizados.

13. O site da revista é agradável.

12. A revista é pontual.

11. No site é fácil visualizar as edições.

10. O site da revista é informativo e claro.
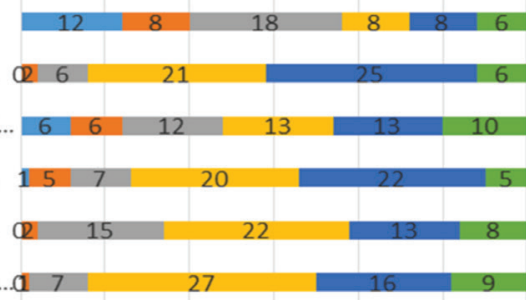

- Grau 1

- Grau 2

- Grau 3

- Grau 4

- Grau 5

n Não opinou

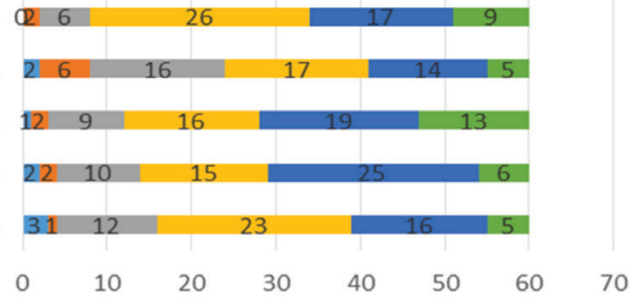

Figura 10. Respostas dos Leitores ao questionário, parte B: (a) percentuais de opiniões sobre meios de mídia que os leitores utilizaram; (b) percentuais de respostas sobre valores que os leitores pagariam pela revista; (c) sequência de perguntas referente ao relacionamento dos leitores com a revista; (d) sequência de perguntas em relação à imagem do sítio eletrônico e mídia impressa junto aos leitores

não ao envio. 35\%, 21 leitores, gostariam de receber os exemplares da revista com a comodidade do envio. 3 leitores, $5 \%$, não respondeu. Finalmente perguntamos se os pesquisados ainda acompanham a revista. $87 \%, 52$ leitores, disseram que continuam acompanhando o conteúdo do periódico. 15\%, 9 leitores, disseram que não mais acompanham a revista. 2\%, 1 leitor, não respondeu. Tal como foi feito nas versões anteriores da pesquisa (autores e revisores), relacionamos 14 perguntas sobre as 
impressões que os leitores pesquisados têm em relação ao sítio eletrônico e a revista impressa (Fig. 10d). As questões foram confeccionadas seguindo também o mesmo modelo da sequência sobre os mesmos assuntos, as quais foram feitas nas pesquisas feitas junto aos autores e revisores do periódico, ou seja, foram requeridas como respostas que o pesquisado relacionasse o grau, em uma escala de 1 a 5 , sendo que um seria referente ao distanciamento daquilo que o pesquisado pensa e 5 sendo o mais próximo possível ao pensamento do leitor.

A primeira questão foi se o site da revista é informativo, claro e apropriado, se ele expõe bem o conteúdo. Houve respostas em todos os graus, sendo que o grau 4 foi o mais relacionado, e os graus 3 e 5 também receberam quantidade considerável de respostas, sendo o grau 5 o segundo mais relacionado como o apropriado como resposta e com apenas 4 respostas de diferença, o grau 3 foi o mais escolhido. Os graus 2 e 1 receberam poucas indicações. 5 Leitores não responderam esta questão. A segunda questão foi se os leitores acreditam se no site da revista é fácil visualizar as edições: a atual e as anteriores. 6 leitores não responderam à questão, mas a grande maioria respondeu com grau 5 , após com quase metade dos votos, vemos o grau 4 e na sequência deste vemos o grau 3 . Os graus 2 e 1, novamente receberam poucos votos. A terceira questão da sequência foi a que mais os leitores se abstiveram em responder, no total vemos 13 pesquisados em um universo de 60, praticamente $22 \%$ do total. A questão relacionada foi se a revista é pontual, se respeita a periodicidade estabelecida. Dos pesquisados restantes, a maioria também elegeu o grau 5 como o mais indicado quanto resposta, seguido pelo grau 4 e após o grau 3. Seguindo os questionamentos anteriores, os graus 2 e 1 receberam poucas respostas. Queríamos saber se os leitores acreditavam que o site é agradável e visualmente adequado. 5 leitores se abstiveram em responder. Nessa questão observamos uma pulverização de respostas entre os graus 5,4 e 3 , sendo que o grau 4 recebeu o maior número de respostas. Tal prevalência, ocorreu por poucas respostas de diferença entre os graus, 4 mais escolhido e os graus 5 e 3 . O grau 2 recebeu mais votos, comparativamente com as questões anteriores. $\mathrm{O}$ grau 1 recebeu apenas um voto.

Outra pergunta aos leitores foi: os artigos publicados são bem organizados e isentos de erros e incorreções? Nessa questão tivemos como resposta um acúmulo no grau 4 e na sequência o grau 5 foi o mais relacionado. Em relação aos graus anteriores o grau 3 recebeu poucas respostas, o grau 2 apenas duas e o grau 1 não recebeu nenhuma. 9 leitores se abstiveram em responder. Ainda sobre os artigos, perguntamos se os textos possuem redação clara, com gramática e sintaxe corretas. Como a pergunta anterior, o grau 4 foi o que mais recebeu respostas, seguido pelo grau 5. O grau 3 recebeu comparativamente aos graus anteriores uma quantidade baixa de respostas. O grau 2 apenas teve uma resposta e o grau 1 nenhuma. 8 pesquisados não responderam. Passamos então a requerer informações sobre ilustrações e tabelas publicadas, sendo que o primeiro questionamento foi se estas são úteis e indispensáveis. Observamos uma concentração grande nos graus 5,4 e 3 , sendo que os graus 2 e 1 , não receberam nenhuma resposta. $\mathrm{O}$ grau 5 recebeu mais respostas, seguido pelo grau $4 \mathrm{e}$ finalmente em menor número o grau 3. 7 leitores se abstiveram em responder. Perguntamos se as ilustrações e tabelas possuem adequado nível de conteúdo e informação. O grau 4 recebeu o maior número de respostas, seguido de perto do grau 5. O grau 3 recebeu poucas respostas quando visto os graus 4 e 5 . O Grau 2 recebeu apenas um voto. $\mathrm{O}$ grau 1 não recebeu nenhuma resposta. 8 leitores não responderam.

Fechando as questões sobre as ilustrações e tabelas, perguntamos se estas são de boa qualidade visual e legibilidade. 9 pesquisados não responderam. O grau 4 recebeu a maioria das respostas, sendo que o grau 5 também obteve uma quantidade considerável. Os graus 3 e 2 foram pouco lembrados entre os pesquisados. O grau 1, novamente, não recebeu nenhuma resposta. Perguntamos então se a importância dos trabalhos publicados é grande. $\mathrm{O}$ grau 4 recebeu a maioria de votos, sendo seguido de perto pelo grau 3 e também pelo grau 5 . O grau 2 recebeu duas respostas, e o grau 1 nenhuma. 8 pesquisados não relacionaram suas respostas. $\mathrm{O}$ resultado, mais uma vez, complementando com as demais pesquisas nos leva a crer que devemos aumentar o interesse de autores reconhecidos em relação à publicação, fazendo com que aumente a percepção e consequentemente também aumentem os índices de qualificação e Fator de Impacto da revista. Em relação ao logotipo da revista, perguntamos se é moderno, de boa qualidade visual e legibilidade. O grau 5 foi o mais escolhido, e quase no mesmo nível o grau 4. O grau 3 comparativamente aos graus anteriores recebeu poucas respostas, como também o grau 2 . O grau 1 recebeu 


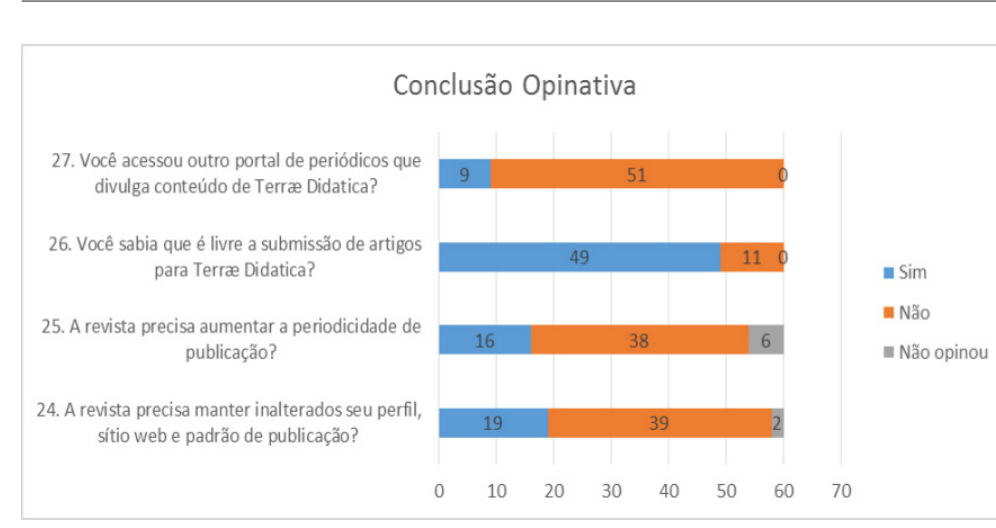

Figura 11. Sequência de perguntas opinativas junto aos leitores com respostas possíveis em sim, não e não opinar, fizemos 4 perguntas aos leitores (Fig. 11).

Perguntamos se a revista precisa manter inalterados seu perfil, sítio web e padrão de publicação? Os leitores em sua maioria acreditam que não. $65 \%$ dos leitores, 39 , relacionaram que a revista precisa alterar seu perfil, sítio web e padrão de publicação. $32 \%$, ou 19 leitores acreditam na imobilidade dos parâmetros relacionados. 2 leiapenas uma resposta.

Outra questão importante relacionada foi se os leitores percebem que a revista possui patrocinadores. 10 pesquisados não responderam. As respostas restantes foram pulverizadas, sendo que o grau 5 e 4, os mais relacionados, receberam o mesmo número de respostas. Sendo que o grau 3 recebeu uma quantidade menor, mas apenas uma resposta a menos que os graus 5 e 4 , ou seja, praticamente a mesma quantidade. Os graus 2 e 1 receberam cada, praticamente a metade da quantidade de respostas dos graus anteriores. Nesta questão, quando analisado o gráfico houve uma pulverização de respostas, o que nos leva a crer que realmente devemos tanto na versão impressa, como na virtual realizarmos um editorial sobre a importância de nossos patrocinadores. Queríamos saber se os leitores percebem como sendo grande a qualidade de Terra Didatica. O grau 5 recebeu a maioria das respostas, e o grau 4 foi igualmente lembrado em relação ao número de respostas recebidas. O grau 3 recebeu poucas respostas, o grau 2 recebeu duas respostas e o grau 1 não recebeu nenhuma resposta. 6 pesquisados não responderam esta questão. Finalmente, perguntamos se os leitores encontram facilmente a revista impressa. O grau 3 foi o mais relacionado entre os leitores, sendo que o grau 1 também recebeu uma quantidade razoável de respostas. Os demais graus receberam exatamente o mesmo número de respostas. 6 leitores não responderam. Parece inadiável levar ao conhecimento dos leitores a possibilidade de receberem a versão impressa em casa pelo ressarcimento de custos, apenas, do envio, ou então distribuirmos mais firmemente junto a bibliotecas de ensino. Para isso necessário se faz que sejam levantadas tais bibliotecas tanto no ensino superior, como em outros níveis e enviar periodicamente a revista a estas instituições.

Como última sequência de perguntas fechadas, tores, 3\%, não responderam. Queríamos saber se os leitores acreditam que seja necessário o aumento da periodicidade de publicação da revista. $63 \%, 38$ leitores, acreditam que não. $27 \%$, 16 , relacionaram que $\operatorname{sim} .10 \%$, ou seja, 6 leitores não responderam. submissão de artigos de para Terræ Didatica Todos os inquiridos responderam essa questão. 49 pesquisados, quase $82 \%$, conheciam a livre submissão, sendo que $18 \%, 11$ pesquisados, não sabiam desta possibilidade. A próxima questão também recebeu todas as respostas, ou seja, todos os pesquisados responderam à pergunta. Perguntamos se os leitores acessaram outros portais os quais divulgam o conteúdo da revista. Maciçamente recebemos o não como resposta, $85 \%$, ou 51 leitores. $15 \%$, ou 9 leitores relacionaram que acessaram o conteúdo do periódico em outros portais na internet. Estranho se torna quando, dentre aqueles que relacionaram que acessaram o conteúdo da revista em outros portais, estudam-se as respostas sobre quais foram tais portais (Fig. 12).

Inicialmente $34 \%$ não apontaram os portais. $22 \%$ apontou o PPEGeo como aquele o qual acessou o conteúdo do periódico o que pode ser somado aos $11 \%$ de leitores que indicaram o portal da USP, o qual entendemos ser o mesmo. O que se torna estranho é quando analisamos os demais portais. Foram apontados ainda no percentual de $11 \%$, os portais da CAPES e SciELO. Terræ Didatica, como indicado, ainda não está indexado ao portal da SciELO e imaginamos que quando relacionado o portal da CAPES esse também seja o SciELO.

O gráfico da Figura 12 mostra algo que balizou na completude a confecção dos gráficos e o presente relato. Reproduzimos de forma fidedigna todas as respostas, sem alterá-las, independentemente das qualidades, pois acreditamos que a precisão está na reprodução exata das respostas, afastando-se qualQuestionamos se os leitores sabiam que é livre a 
Qual outro portal de periódicos que acessou a TD

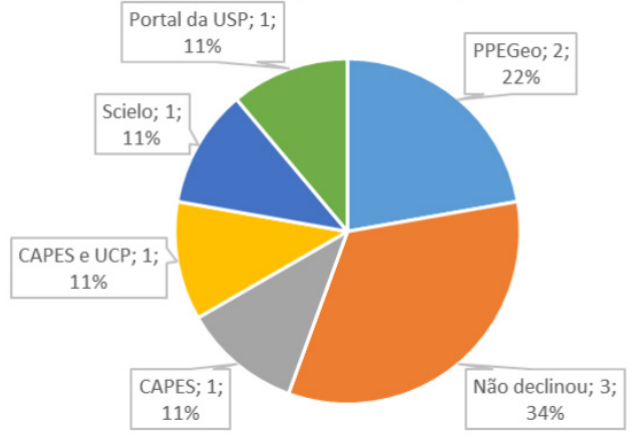

Figura 12. Portais nos quais os leitores acessaram o conteúdo da revista

quer alteração por nossa parte, o que poderia ser nociva e gerar interpretações errôneas.

Como nas outras versões da pesquisa, foi aberto espaço para sugestões, opiniões e outras informações que os leitores gostariam de relacionar: o que vimos foram também maciços pedidos de reformulação do sítio eletrônico. Alguns ressaltaram a importância da indexação da revista em plataformas de Acesso Livre e Impac Factor. Tivemos pedidos de aumento de divulgação junto às escolas de ensino básico e médio. Outras colocações um pouco conflitantes foram que deveriam haver somente artigos aceitos em português, quanto outros pediram artigos em espanhol.

\section{Discussão}

A quantidade de respostas obtidas na pesquisa junto a revisores, autores e leitores não foram expressivas porém aportaram informações relevantes que podem ajudar a reorientar o periódico. Comparando-se os dados de número de participantes em relação ao universo potencial, obtivemos 34 respostas de 283 Autores, ou seja, 12,01\% do total; 28 respostas dentre um total de 70 Revisores consultados, o que equivale a $40,0 \%$ do total; e 60 respostas dentre mais de 500 Leitores consultados, ou seja, menos de $12,0 \%$ do total. Essa dificuldade tem sido encontrada em pesquisas baseadas no preenchimento de questionários, uma vez que, por mais simples e diretos que sejam os instrumentos de pesquisa utilizados, cada pessoa consultada precisa dispor de uma parcela de seu precioso tempo para ler as questões, meditar sobre elas, atribuir respostas e, ao final do processo, devolver o conjunto preenchido ao pesquisador.

A análise dos diagramas e gráficos apresentados neste trabalho revela que os respondentes avaliam de maneira muito favorável os diversos aspectos que compõem o perfil editorial de Terre Didatica. Até mesmo em relação a prazos de avaliação, percebe-se certa tolerância; com efeito, a revisão editorial por vezes ultrapassa em várias semanas o prazo inicial, de no máximo quatro semanas. $\mathrm{O}$ problema não é exclusivo desta revista mas pode levar autores a dirigir sua produção a outras revistas da área, nacionais ou internacionais.

Para o aumento da qualificação da revista é necessário alterar a análise inicial de documentos a serem publicados, que deveria ser mais rápida e rigorosa. Também identificou-se a necessidade de aumentar a penetração em todos os níveis nas instituições públicas de ensino e a visualização em instituições particulares de ensino superior, o que hoje ainda não acontece. A alternativa mais adequada para tal popularização pode estar nas redes sociais.

A fusão dos dois periódicos da área de Geociências da Unicamp, divulgada em recente editorial de Terre Didatica (Os editores 2018) abre espaço para investigação adicional, uma vez que os dados obtidos na presente pesquisa antecedem tal decisão.

\section{Conclusões}

Os dados recolhidos na pesquisa revelam que Terra Didatica está firmemente apoiada em amplo espectro de revisores que formam seleto conselho editorial. As respostas permitem constatar que os leitores, os autores, e os especialistas que têm sido convidados a emitir avaliações editoriais constituem público-alvo capaz de incrementar a divulgação de Geociências na sociedade brasileira e até mesmo consolidar uma comunidade atuante no plano internacional.

Vamos rever a pergunta inicial: a revista Terre Didatica fortalece o ensino de Geociências e cumpre adequadamente seu papel de veículo de difusão do conhecimento geocientífico? A resposta não poderia deixar de ser: "Há muito ainda no que se trabalhar!"

Como vimos, Terrex Didatica trilhou já um longo caminho. Ela se predispõe a fortalecer o ensino de Geociências, pois é orientada por editores, autores, revisores e demais colaboradores nesse propósito, cumprindo seu papel como ferramenta de livre acesso a todos. Conta com inúmeros documentos publicados, das mais diversas ordens. Sendo o objetivo a difusão plena das Geociências, TD deverá conter também textos capazes de engajar os alunos das primeiras séries do ensino básico, 
com linguagem mais leve e focalizando assuntos diretamente ligados a suas experiências e expectativas em relação à matéria. Talvez neste contexto seja necessário um pequeno ajuste no olhar do corpo editorial quanto a temas abordados nos textos, incluindo tal necessidade nos veículos de divulgação da revista. Outra alternativa seria o uso de plataformas tecnológicas avançadas, tais como realidade aumentada ou virtual, fazendo assim com que o aluno obtenha uma imersão e possa beneficiar-se do ensino e da aprendizagem no assunto, mesmo nos textos mais técnicos e pesados.

Isto posto, a publicação, livremente acessível, principalmente quando se utiliza a internet como plataforma de divulgação, dá um passo a mais na busca do pleno e inalcançável sim da resposta de tal pergunta, pois o conteúdo ali disposto precisa apenas que o leitor saiba de sua existência, para que possa ganhar um universo novo dentro das Geociências. As respostas valorizam o esforço de TD em divulgar artigos de alta qualidade, tanto técnicos quanto didáticos, como tem sido feito acertadamente até agora. A publicação deve operar em outras frentes, que não apenas as instituições públicas de ensino superior; precisa ser apresentada e estar sempre disponível também para professores de outros níveis de ensino pois, como vimos na pesquisa, a impressão dos leitores, autores e revisores é de que é alta a importância da revista e daquilo que publica.

\section{Agradecimentos}

Os autores agradecem a cada leitor, colega, professor, pesquisador, estudante e profissional que se dispôs a dedicar uma parte de seu tempo valioso para responder à enquete da qual resulta este artigo. Agradecem ao CNPq, Conselho Nacional de Desenvolvimento Científico e Tecnológico pela concessão de Bolsa de Produtividade em Pesquisa, nível 2, para o segundo autor (CDRC).

\section{Referências}

Carneiro C.D.R., Linquevis F.L. 2018. Abordagem para avaliação de desempenho de periódicos: aplicação à revista Terræ Didatica, área de Geociências. Campinas: Rev. digit. bibliotecon. cienc. inf., (a submeter, maio de 2018).

Linquevis F.L. 2017. A revista Terræ Didatica como veículo de difusão do conhecimento de Geociências. Campinas: Inst. Geoc., Unicamp. 172p. (Dissert. Mestrado).

Menegat R., Mizusaki A.M.P., Remus M., Lelarge L.M.V. Dani N. 2014. Inovação no paradigma curricular: os Projetos Temáticos em Geologia. Terre Didatica. 10(3):215. URL: http://www.ige. unicamp.br/terraedidatica/V10_3/PDF/TDv10-3113.pdf. Acesso 13/09/2017.

Os Editores. 2018. Terre Didatica e Terrce agora são uma só, no ambiente Open Journal Systems. Terrce Didatica, 14(1):1-4. (Editorial). URL: . Acesso 31.03.2018.

Verma I.M. 2015. Impact, not impact factor. PNAS, Proc. Nat. Acad. Sciences United States of America, 112(26):7875-7876. URL: http://www.pnas.org/ content/112/26/7875.full. Acesso em 13.09.2017. 